\title{
THE CONFINEMENT OF CONCRETE IN COMPRESSION USING CFRP COMPOSITES - EFFECTIVE DESIGN EQUATIONS
}

\author{
Riad BENZAID ${ }^{\mathrm{a}}$, Habib-Abdelhak MESBAH ${ }^{\mathrm{b}}$ \\ ${ }^{a}$ L.G.G., Jijel University-B.P. 98, Cité Ouled Issa, 18000 Jijel, Algeria \\ ${ }^{b}$ L.G.C.G.M., INSA of Rennes 20, Av. des Buttes de Coësmes-CS 70839-35708-Rennes Cedex 7, France
}

Received 12 Feb 2012; accepted 30 Mar 2012

\begin{abstract}
This paper presents the results of an experimental study on the behaviour of axially loaded short concrete columns, with different cross sections that have been externally strengthened with carbon fibre-reinforced polymer (CFRP) sheets. Six series, forming the total of 60 specimens, were subjected to axial compression. All the test specimens were loaded to failure in axial compression and investigated in both axial and transverse directions. According to the obtained test results, FRP-confined specimen failure occurs before the FRP reached the ultimate strain capacities. Thus, the failure occurs prematurely and the circumferential failure strain is lower than the ultimate strain obtained from the standard tensile testing of the FRP composite. In existing models for FRP-confined concrete, it is commonly assumed that the FRP ruptures when the hoop stress in the FRP jacket reaches its tensile strength from either flat coupon tests, which is herein referred to as the FRP material tensile strength. This phenomenon considerably affects the accuracy of the existing models for FRP-confined concrete. On the basis of the effective lateral confining pressure of the composite jacket and the effective circumferential FRP failure strain, new equations were proposed to predict the strength of FRP-confined concrete and corresponding strain for each of the cross section geometry used, circular and square. The estimations given by these equations were compared with the experimental ones and general conclusions were drawn.
\end{abstract}

Keywords: CFRP sheets, confinement, columns, strengthening, stress, strain.

\section{Introduction}

The use of fibre reinforced polymer (FRP) jackets as an external mean to strengthen existing RC columns has emerged in recent years with very promising results (Saadatmanesh et al. 1994; Mirmiran et al. 1998; Shehata et al. 2002; Chaallal et al. 2003; Campione et al. 2004; Matthys et al. 2005; Wu et al. 2006; Almusallam 2007; Benzaid et al. 2008; Rousakis, Karabinis 2008; Benzaid et al. 2009, 2010; Piekarczyk et al. 2011). Several studies on the performance of FRP wrapped columns have been conducted, using both experimental and analytical approaches. Such strengthening technique has proved to be very effective in enhancing their ductility and axial load capacity. However, the majority of such studies have focused on the performance of columns of circular cross section. The data available for columns of square or rectangular cross sections have increased over recent years but are still limited. This field remains in its developmental stages and more testing and analysis are needed to explore its capabilities, limitations, and design applicability.

This study deals with a series of tests on circular and square plain concrete (PC) and reinforced concrete (RC) columns strengthened with carbon fibre reinforced polymer (CFRP) sheets. The total of 60 concrete specimens was tested under axial compression. The data recorded included the compressive stress, axial and radial-strains.
The parameters considered are the number of composite layers ( 1 and 3 ), the compressive strength of the unconfined concrete (normal-strength $26 \mathrm{MPa}$, mediumstrength $50 \mathrm{MPa}$ and high-strength $62 \mathrm{MPa}$ ) and the cross-section shape (circular and square). The effective circumferential FRP failure strain and the effective lateral confining pressure of a composite jacket were investigated. All test specimens were loaded to failure in axial compression and investigated mostly in both axial and transverse directions. As, for practical design, it is sufficient to know the compressive strength and the ultimate strain of confined concrete, this work focuses only on the evaluation of their values and no attempts are made to obtain the complete stress-strain curve of confined concrete. The predictions of the proposed equations are shown to agree well with the test data.

\section{Observed behaviour of FRP-confined concrete}

\subsection{FRP-confined concrete in circular columns}

The confinement action exerted by the FRP on the concrete core is of the passive type, that is, it arises as a result of the lateral expansion of concrete under axial load. As the axial stress increases, the corresponding lateral strain increases and the confining device develops a tensile hoop stress balanced by a uniform radial pressure, which reacts against 
the concrete lateral expansion (De Lorenzis, Tepfers 2001, 2003). When a FRP-confined cylinder is subject to axial compression, concrete expands laterally and this expansion is restrained by the FRP. The confining action of the FRP composite for circular concrete columns is shown in Figure 1. For circular columns, concrete is subject to uniform confinement, and the maximum confining pressure provided by FRP composite is related to the amount and strength of FRP and the diameter of the confined concrete core. The maximum value of the confinement pressure that the FRP can exert is attained when the circumferential strain in the FRP reaches its ultimate strain and the fibres rupture leading to brittle failure of the cylinder. This confining pressure is given by:

$$
f_{l}=\frac{2 t_{f r p} E_{f r p} \varepsilon_{f u}}{d}=\frac{2 t_{f r p} f_{f r p}}{d}=\frac{\rho_{f r p} f_{f r p}}{2},
$$

where: $f_{l}$ is the lateral confining pressure; $E_{f r p}$ is the elastic modulus of the FRP composite; $\varepsilon_{f u}$ is the ultimate FRP tensile strain; $f_{f r p}$ is the ultimate tensile strength of the FRP composite; $t_{f r p}$ is the total thickness of the FRP; $d$ is the diameter of the concrete cylinder; and $\rho_{f i p}$ is the FRP volumetric ratio given by the following equation for fully wrapped circular cross section:

$$
\rho_{f r p}=\frac{\pi d t_{f r p}}{\pi d^{2} / 4}=\frac{4 t_{f r p}}{d} .
$$

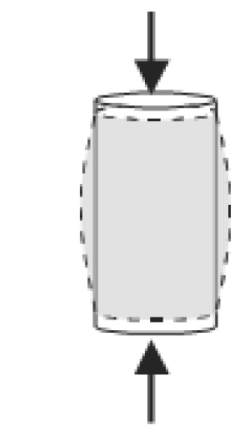

FRP-Confined concrete

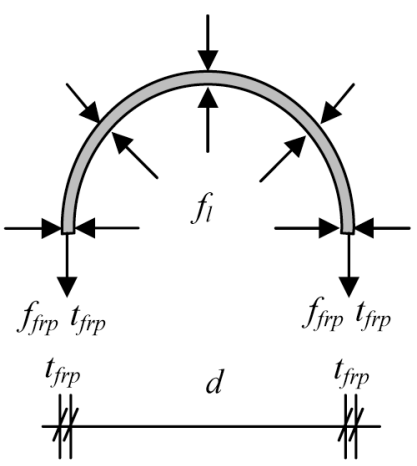

Confining pressure
Fig. 1. Confinement action of FRP jacket in circular sections

\subsection{FRP-confined concrete in square columns}

A square column with rounded corners is shown in Figure 2. To improve the effectiveness of FRP confinement, corner rounding is generally recommended. Due to the presence of internal steel reinforcement, the corner radius $\mathrm{Rc}$ is generally limited to small values. Existing studies on steel confined concrete (Park, Paulay 1975; Mander et al. 1988; Cusson, Paultre 1995) have led to the simple proposition that concrete in a square section is confined by the transverse reinforcement through arching actions, and only the concrete contained by the four second-degree parabolas as shown in Figure $2 \mathrm{a}$ is fully confined while the confinement to the rest is negligible. These parabolas intersect the edges at $45^{\circ}$. While there are differences between steel and FRP in providing confinement, the observation that only part of the section is well confined is obviously also valid in the case of FRP confinement. Youssef et al. (2007) showed that confining square concrete members with FRP materials tends to produce confining stress concentrated around the corners of such members, as shown in Figure $2 b$. The reduced effectiveness of a FRP jacket for a square section than for a circular section has been confirmed by experimental results (Mirmiran et al. 1998; Rochette, Labossière 2000). Despite this reduced effectiveness, an FRP-confined square concrete column generally also fails by FRP rupture (Benzaid et al. 2008; Rochette, Labossière 2000).

In Eqn (1), $d$ is replaced by the diagonal length of the square section. For a square section with rounded corners, $d$ can be written as:

$$
d=\sqrt{2} b-2 \operatorname{Rc}(\sqrt{2}-1) .
$$

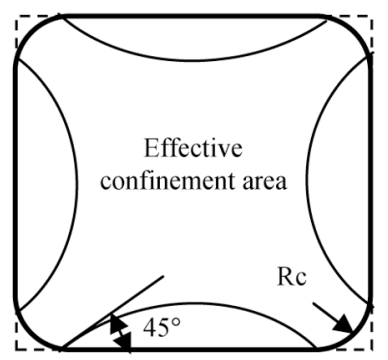

(a) Effectively confined concrete in a square column

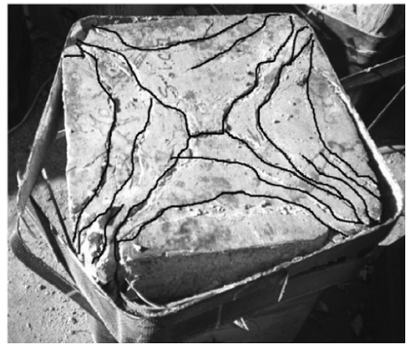

(b) Dilated square column confined with carbon/epoxy jacket (Youssef et al. 2007)
Fig. 2. Confinement action of FRP composite in square sections

\section{Experimental program}

\subsection{Material properties}

Concrete mixtures. Three concrete mixtures were used to achieve the desired range of unconfined concrete strength (26, 50 and $62 \mathrm{MPa})$, as shown in Table 1. Mixtures were prepared in the laboratory using a mechanical mixer and were used to cast the concrete specimens, which were wrapped with CFRP sheets after drying.

CFRP composites. The carbon-fibre fabric used in this study was the SikaWrap-230C/45 product, a unidirectional wrap. The resin system that was used to bond the carbon fabrics over the specimens in this work was the epoxy resin made of two-parts, resin and hardener. The mixing ratio of the two components by weight was $4: 1$. SikaWrap-230C/45 was field laminated using Sikadur-330 epoxy to form a carbon fibre reinforced polymer wrap (CFRP) used to strengthen the concrete specimens.

The mechanical properties, including the modulus and the tensile strength of the CFRP composite, were obtained through tensile testing of flat coupons. The tensile tests were conducted essentially following the NF EN ISO 527-(1, 2 and 5) recommendations. The tensile specimen configuration is represented in Figure 3a. All of the test coupons were allowed to cure in the laboratory environment for at least 7 days. Prior to testing, aluminium plates were glued to the ends of the coupons to avoid 
Table 1. Concrete mixture proportions

\begin{tabular}{lccc}
\hline \multicolumn{1}{c}{ Mixture no. } & I & II & III \\
\hline $\begin{array}{l}\text { Compressive cylinder } \\
\text { strength, } f_{c o}(\mathrm{MPa})\end{array}$ & 25.93 & 49.46 & 61.81 \\
Cement $\left(\mathrm{kg} / \mathrm{m}^{3}\right)$ & & & \\
Water $\left(\mathrm{kg} / \mathrm{m}^{3}\right)$ & $280^{\mathrm{a}}$ & $400^{\mathrm{b}}$ & $450^{\mathrm{c}}$ \\
Crushed gravel $\left(\mathrm{kg} / \mathrm{m}^{3}\right)$ & 180 & 183.86 & 170 \\
$\quad$ & & & \\
$\varnothing 4 / 6$ & 122.90 & 115.70 & 115.60 \\
$\varnothing 6 / 12$ & 258.20 & 243.00 & 242.80 \\
$\varnothing 12 / 20$ & 769.50 & 724.20 & 723.50 \\
Sand Ø 0/4 $\left(\mathrm{kg} / \mathrm{m}^{3}\right)$ & 729.10 & 686.30 & 685.60 \\
Sika Viscocrete-Tempo12 & - & 0.85 & 1.55 \\
$\left(\mathrm{l} / \mathrm{m}^{3}\right)$, & & & \\
Air content $(\%)$ & 2.3 & 2.5 & 2.7 \\
W/C & 0.64 & 0.46 & 0.37 \\
\hline
\end{tabular}

${ }^{a}$ Portland cement: CPA CEM II R $32.5 \mathrm{MPa}$;

${ }^{b}$ Portland cement: CPA CEM I R 42.5 MPa;

'Portland cement: CPA CEM I R 52.5 MPa;

${ }^{\mathrm{d}}$ Sika Viscocrete-Tempo 12: High-range water reducing and super-plasticizing admixture.
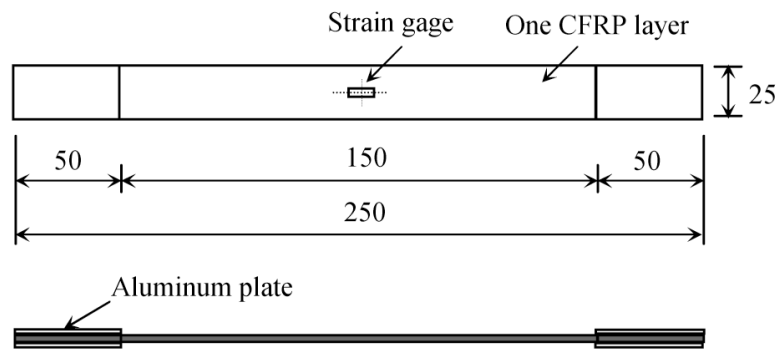

(a) Dimensions of CFRP flat coupons

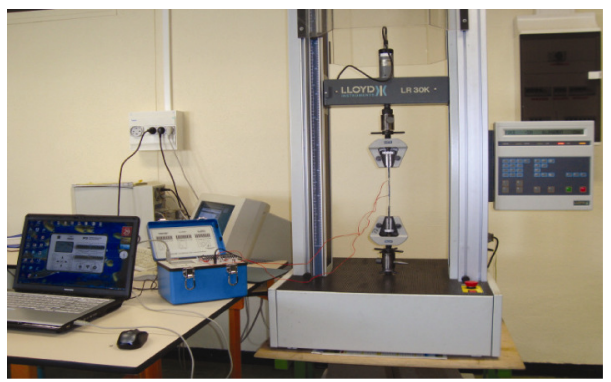

(b) CFRP specimen being tested in the direct tension

Fig. 3. Flat coupon tensile tests

premature failure of coupon ends, which were clamped in the jaws of the testing machine. The tests were carried out under displacement control at a rate of $1 \mathrm{~mm} / \mathrm{min}$. The longitudinal strains were measured using strain gages at mid-length of the test coupon. The load and strain readings were taken using a data logging system and were stored in a computer (Fig. 3b). Main mechanical properties obtained from the average values of the tested coupons are summarized below:

- Thickness (per ply): $1 \mathrm{~mm}$;

- Modulus $E_{f r p}: 34 \mathrm{GPa}$;

- Tensile strength $f_{f r p}: 450 \mathrm{MPa}$;

- Ultimate strain $\varepsilon_{f u}: 14 \%$.
Note that the tensile strength was defined based on the cross-sectional area of the coupons, while the elastic modulus was calculated from the stress-strain response.

\subsection{Fabrication of test specimens}

The experimental program was carried out on: 1) cylindrical specimens with a diameter of $160 \mathrm{~mm}$ and a height of $320 \mathrm{~mm}$; 2) short column specimens with a square cross section of $140 \times 140 \mathrm{~mm}$ and a height of $280 \mathrm{~mm}$. For all RC specimens, the diameter of longitudinal and transverse reinforcing steel bars were respectively $12 \mathrm{~mm}$ and $8 \mathrm{~mm}$. The longitudinal steel ratio was constant for all specimens and equal to $2.25 \%$. The yield strength of the longitudinal and transversal reinforcement was $500 \mathrm{MPa}$ and $235 \mathrm{MPa}$; respectively. The specimen notations are as follows: the first letter refers to section shape $-\mathrm{C}$ for circular and $\mathrm{S}$ for square. The next two letters indicate the type of concrete - PC for plain concrete and RC for reinforced concrete, followed by the concrete mixture: I for normal strength (26 MPa), II for medium strength $(50 \mathrm{MPa})$ and III for high strength (62 MPa). The last letters specifies the number of CFRP layers $(0 \mathrm{~L}, 1 \mathrm{~L}$ and $3 \mathrm{~L})$, followed by the number of a specimen.

After 28 days of curing, the CFRP jackets were applied to the specimens by manual wet lay-up process. The concrete specimens were cleaned and completely dried before the resin was applied. The mixed Sikadur-330 epoxy resin was directly applied onto the substrate at a rate of $0.7 \mathrm{~kg} / \mathrm{m}^{2}$. The fabric was carefully placed into the resin with gloved hands and any irregularities or air pockets were smoothened out using a plastic laminating roller. The roller was continuously used until the resin was reflected on the surface of the fabric, an indication of fully wetting. After the application of the first CFRP wrap, the second layer of resin at a rate of $0.5 \mathrm{~kg} / \mathrm{m}^{2}$ was applied to allow the impregnation of the second layer of the CFRP. The following layer is applied in the same way. Finally, a layer of resin was applied to complete the operation. The last CFRP layer was wrapped around the column with an overlap of $1 / 4$ of the perimeter to avoid sliding or deboning of fibres during tests and to ensure the development of full composite strength (Shahawy et al. 2000; Benzaid et al. 2010). The wrapped specimens were left at room temperature for 1 week for the epoxy to harden adequately before testing. Specimens involved in the experimental work are indicated in Table 2. Figure 4 shows samples of the wrapped specimens.

\subsection{Test procedure}

Specimens were loaded under a monotonic uni-axial compression load up to failure. The compressive load was applied at a rate corresponding to $0.24 \mathrm{MPa} / \mathrm{s}$ and was recorded with an automatic data acquisition system. Axial and lateral strains were measured using appreciable extensometer. The instrumentation included one radial linear variable differential transducer (LVDT) placed in the form of a hoop at the mid-height of the specimens. Measurement devices also included three vertical LVDTs to 
measure the average axial strains. Prior to testing, all CFRP-wrapped specimens were capped with sulfur mortar at both ends. The test setup is shown in Figure 5.

\section{Experimental results and discussion}

In the following section, the test results are presented, including the different stress-strain responses of the confined concrete. Factors affecting the confinement effectiveness, that is, unconfined concrete strength, thickness of the CFRP jacket and the shape of cross section, and failure modes are discussed.

Table 2. Details of test specimens

\begin{tabular}{|c|c|c|c|c|c|}
\hline $\begin{array}{l}\text { Specimen } \\
\text { designation }\end{array}$ & $\begin{array}{l}\text { Concrete } \\
\text { mixture }\end{array}$ & $\begin{array}{l}\text { Nominal dimensions } \\
\text { (diameter } \times \text { height })[\mathrm{mm}]\end{array}$ & $\begin{array}{c}\text { Number of CFRP } \\
\text { layers }\end{array}$ & $\begin{array}{l}\text { Number of } \\
\text { specimens }\end{array}$ & $\begin{array}{l}\text { Unconfined concrete } \\
\text { strength [MPa] }\end{array}$ \\
\hline CPCI.0L & & & 0 & 2 & \multirow{12}{*}{26} \\
\hline CPCI.1L & & & 1 & 1 & \\
\hline CPCI.3L & I & $160 \times 320$ & 3 & 1 & \\
\hline CRCI.0L & & & 0 & 2 & \\
\hline CRCI.1L & & & 1 & 2 & \\
\hline CRCI.3L & & & 3 & 2 & \\
\hline SPCI.0L & \multirow{6}{*}{ I } & \multirow{6}{*}{$140 \times 140 \times 280$} & 0 & 2 & \\
\hline SPCI.1L & & & 1 & 1 & \\
\hline SPCI.3L & & & 3 & 1 & \\
\hline SRCI.0L & & & 0 & 2 & \\
\hline SRCI.1L & & & 1 & 2 & \\
\hline SRCI.3L & & & 3 & 2 & \\
\hline CPCII.0L & \multirow{6}{*}{ II } & \multirow{6}{*}{$160 \times 320$} & 0 & 2 & \multirow{12}{*}{50} \\
\hline CPCII.1L & & & 1 & 1 & \\
\hline CPCII.3L & & & 3 & 1 & \\
\hline CRCII.0L & & & 0 & 2 & \\
\hline CRCII.1L & & & 1 & 2 & \\
\hline CRCII.3L & & & 3 & 2 & \\
\hline SPCII.0L & \multirow{6}{*}{ II } & \multirow{6}{*}{$140 \times 140 \times 280$} & 0 & 2 & \\
\hline SPCII.1L & & & 1 & 1 & \\
\hline SPCII.3L & & & 3 & 1 & \\
\hline SRCII.0L & & & 0 & 2 & \\
\hline SRCII.1L & & & 1 & 2 & \\
\hline SRCII.3L & & & 3 & 2 & \\
\hline CPCIII.0L & \multirow{6}{*}{ III } & \multirow{6}{*}{$160 \times 320$} & 0 & 2 & \multirow{12}{*}{62} \\
\hline CPCIII.1L & & & 1 & 1 & \\
\hline CPCIII.3L & & & 3 & 1 & \\
\hline CRCIII.0L & & & 0 & 2 & \\
\hline CRCIII.1L & & & 1 & 2 & \\
\hline CRCIII.3L & & & 3 & 2 & \\
\hline SPCIII.0L & \multirow{6}{*}{ III } & \multirow{6}{*}{$140 \times 140 \times 280$} & 0 & 2 & \\
\hline SPCIII.1L & & & 1 & 1 & \\
\hline SPCIII.3L & & & 3 & 1 & \\
\hline SRCIII.0L & & & 0 & 2 & \\
\hline SRCIII.1L & & & 1 & 2 & \\
\hline SRCIII.3L & & & 3 & 2 & \\
\hline
\end{tabular}

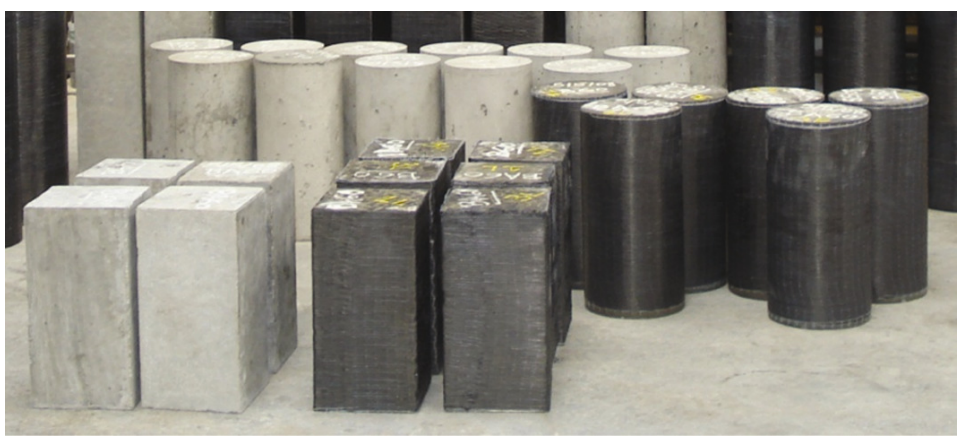

Fig. 4. Samples of specimens after curing and wrapping $\left(f^{\prime}{ }_{c o}=60 \mathrm{MPa}\right)$

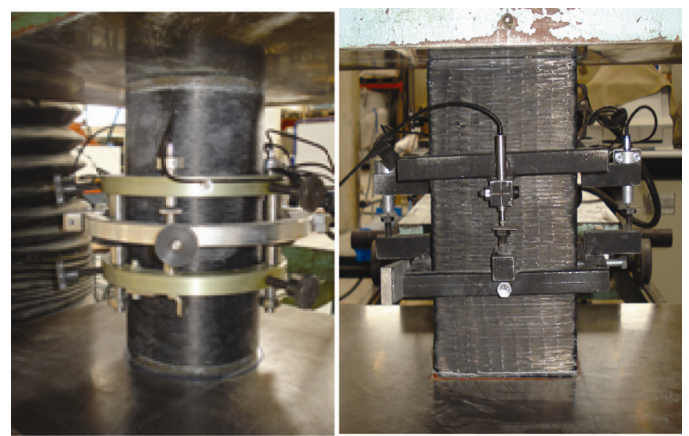

Fig. 5. Test setup 
Table 3. Mean-values of experimental results of CFRP-wrapped specimens

\begin{tabular}{|c|c|c|c|c|c|c|c|c|}
\hline $\begin{array}{l}\text { Concrete mix- } \\
\text { ture }\end{array}$ & $\begin{array}{l}\text { Specimen } \\
\text { Code }\end{array}$ & $\begin{array}{c}f_{c o}^{\prime} \\
{[\mathrm{MPa}]}\end{array}$ & $\begin{array}{c}f_{c c}^{\prime} \\
{[\mathrm{MPa}]}\end{array}$ & $f^{\prime}{ }_{c d} / f^{\prime}{ }_{c o}$ & $\begin{array}{c}\varepsilon_{c c} \\
{[\% \mathbf{\%}]}\end{array}$ & $\varepsilon_{c c /} \varepsilon_{c o}$ & $\begin{array}{l}\varepsilon_{h, r u p} \\
{[\% 0]}\end{array}$ & $\varepsilon_{h, \text { rup }} \varepsilon_{h o}$ \\
\hline \multirow{6}{*}{ I (26MPa) } & CPCI.0L & \multirow{3}{*}{25.93} & 25.93 & 1.00 & 2.73 & 1.00 & 1.77 & 1.00 \\
\hline & CPCI.1L & & 39.63 & 1.52 & 12.78 & 4.68 & 13.12 & 7.41 \\
\hline & CPCI.3L & & 66.14 & 2.55 & 15.16 & 5.55 & 13.18 & 7.44 \\
\hline & CRCI.0L & \multirow{3}{*}{29.51} & 29.51 & 1.00 & 3.77 & 1.00 & 4.95 & 1.00 \\
\hline & CRCI.1L & & 49.88 & 1.69 & 15.34 & 4.06 & 13.15 & 2.65 \\
\hline & CRCI.3L & & 71.35 & 2.41 & 22.98 & 6.09 & 13.24 & 2.67 \\
\hline \multirow{6}{*}{ II (50MPa) } & CPCII.0L & \multirow{3}{*}{49.46} & 49.46 & 1.00 & 1.69 & 1.00 & 1.33 & 1.00 \\
\hline & CPCII.1L & & 52.75 & 1.06 & 2.52 & 1.49 & 2.90 & 2.18 \\
\hline & CPCII.3L & & 82.91 & 1.67 & 7.27 & 4.30 & 13.15 & 9.88 \\
\hline & CRCII.0L & \multirow{3}{*}{58.24} & 58.24 & 1.00 & 3.02 & 1.00 & 5.05 & 1.00 \\
\hline & CRCII.1L & & 77.51 & 1.33 & 8.36 & 2.76 & 13.16 & 2.60 \\
\hline & CRCII.3L & & 100.41 & 1.72 & 13.58 & 4.49 & 13.18 & 2.61 \\
\hline \multirow{6}{*}{ III (62MPa) } & CPCIII.0L & \multirow{3}{*}{61.81} & 61.81 & 1.00 & 2.64 & 1.00 & 2.40 & 1.00 \\
\hline & CPCIII.1L & & 62.68 & 1.01 & 3.04 & 1.15 & 2.46 & 1.02 \\
\hline & CPCIII.3L & & 93.19 & 1.50 & 9.80 & 3.71 & 12.89 & 5.37 \\
\hline & CRCIII.0L & \multirow{3}{*}{63.01} & 63.01 & 1.00 & 2.69 & 1.00 & 4.90 & 1.00 \\
\hline & CRCIII.1L & & 76.21 & 1.20 & 3.75 & 1.39 & 5.20 & 1.06 \\
\hline & CRCIII.3L & & 94.81 & 1.50 & 6.18 & 2.29 & 5.62 & 1.14 \\
\hline \multirow{6}{*}{ I (26MPa) } & SPCI.0L & \multirow{3}{*}{24.77} & 24.77 & 1.00 & 2.17 & 1.00 & 3.62 & 1.00 \\
\hline & SPCI.1L & & 27.66 & 1.11 & 5.58 & 2.57 & 12.23 & 3.37 \\
\hline & SPCI.3L & & 32.03 & 1.29 & 6.05 & 2.78 & 13.23 & 3.65 \\
\hline & SRCI.0L & \multirow{3}{*}{33.59} & 33.59 & 1.00 & 4.29 & 1.00 & 9.38 & 1.00 \\
\hline & SRCI.1L & & 41.02 & 1.22 & 6.08 & 1.41 & 11.58 & 1.23 \\
\hline & SRCI.3L & & 49.12 & 1.46 & 8.40 & 1.95 & 14.38 & 1.53 \\
\hline \multirow{6}{*}{ II (50MPa) } & SPCII.0L & \multirow{3}{*}{48.53} & 48.53 & 1.00 & 3.38 & 1.00 & 3.83 & 1.00 \\
\hline & SPCII.1L & & 52.52 & 1.08 & 4.03 & 1.19 & 7.34 & 1.91 \\
\hline & SPCII.3L & & 58.25 & 1.20 & 6.72 & 1.98 & 9.88 & 2.57 \\
\hline & SRCII.0L & \multirow{3}{*}{52.82} & 52.82 & 1.00 & 4.07 & 1.00 & 7.50 & 1.00 \\
\hline & SRCII.1L & & 62.04 & 1.17 & 5.41 & 1.32 & 8.56 & 1.14 \\
\hline & SRCII.3L & & 69.09 & 1.30 & 6.89 & 1.69 & 10.83 & 1.44 \\
\hline \multirow{6}{*}{ III (62MPa) } & SPCIII.0L & \multirow{3}{*}{59.53} & 59.53 & 1.00 & 3.56 & 1.00 & 3.89 & 1.00 \\
\hline & SPCIII.1L & & 61.30 & 1.02 & 3.69 & 1.03 & 3.97 & 1.02 \\
\hline & SPCIII.3L & & 70.35 & 1.18 & 4.94 & 1.38 & 6.69 & 1.71 \\
\hline & SRCIII.0L & \multirow{3}{*}{63.79} & 63.79 & 1.00 & 3.75 & 1.00 & 5.71 & 1.00 \\
\hline & SRCIII.1L & & 74.84 & 1.17 & 3.87 & 1.03 & 5.74 & 1.01 \\
\hline & SRCIII.3L & & 79.59 & 1.24 & 5.14 & 1.37 & 7.96 & 1.39 \\
\hline
\end{tabular}

\subsection{Overall behaviour}

Compression behaviour of the CFRP wrapped specimens was mostly similar in each series in terms of stress-strain curves and failure modes of the columns. From the average experimental results reported in Table 3 , it can be seen that the increase in strength and axial strain varied according to the unconfined concrete strength, the cross section shape and the amount of confinement provided by CFRP (expressed in number of layers).

The test results described in Table 3 indicate that CFRP-confinement can significantly enhance the ultimate strengths and strains of both plain- and RC-columns. As observed for normal-strength RC specimens (26 MPa) with circular and square cross-sections, the average increase in strength were in the order of $69 \%$ and $22 \%$ over its unconfined concrete strength for columns with 1 layer, $141 \%$ and $46 \%$ for columns with 3 layers of CFRP jackets, respectively, while the respective values for medium- strength concrete $(50 \mathrm{MPa})$ were $33 \%$ and $17 \%$ for 1 layer, $72 \%$ and $30 \%$ for 3 layers of CFRP jackets. Regarding high-strength concrete specimens (62 $\mathrm{MPa})$ with circular and square cross-sections, $f_{c c}^{\prime}$, increased on average $20 \%$ and $17 \%$ for 1 layer, $50 \%$ and $24 \%$ for CFRP jackets of 3 layers, respectively.

The axial strains corresponding to CFRP-confined columns $\left(\varepsilon_{c c}\right)$, for the normal-strength RC specimens with circular and square cross-sections, were on average 4.06 and 1.41 times that of unconfined concrete $\left(\varepsilon_{c o}\right)$ for 1 layer, 6.09 and 1.95 times for 3 layers of CFRP jackets, respectively, while the respective values for mediumstrength concrete were 2.76 and 1.32 times for 1 layer, 4.49 and 1.69 times for 3 layers. For high-strength concrete specimens with circular and square cross-sections, $\varepsilon_{c c}$, increased 1.39 and 1.03 times for 1 layer, 2.29 and 1.37 times for CFRP jackets of 3 layers, respectively.

Figure 6 shows the increase in compressive strength versus the unconfined concrete strength $f_{c o}$ for plain and 

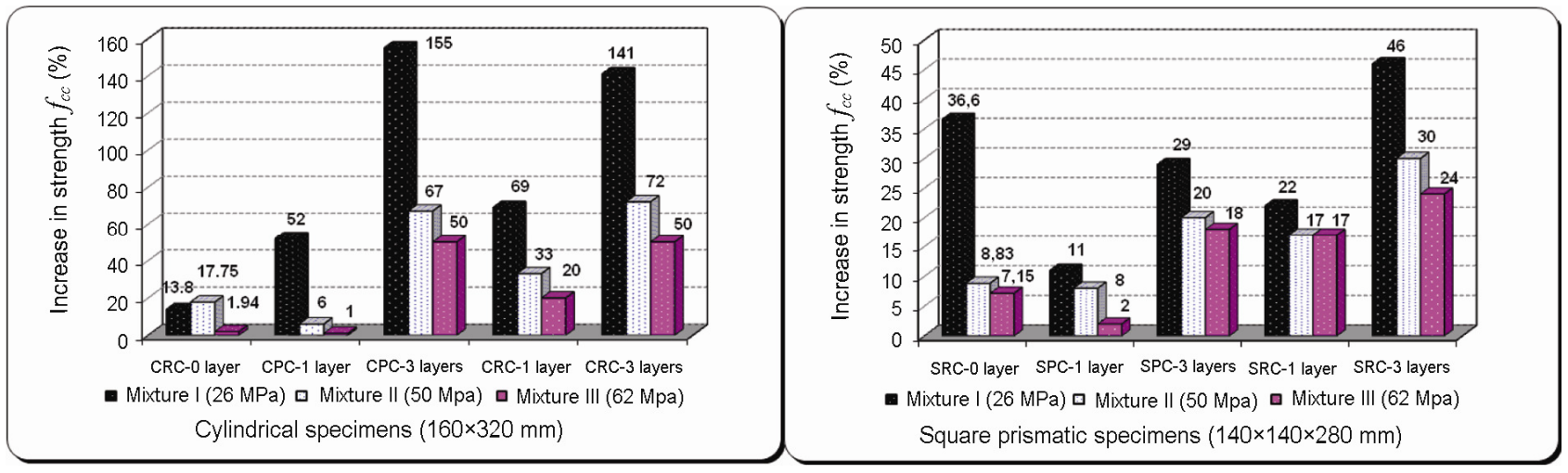

Fig. 6. Effect of unconfined strength of concrete on peak stresses
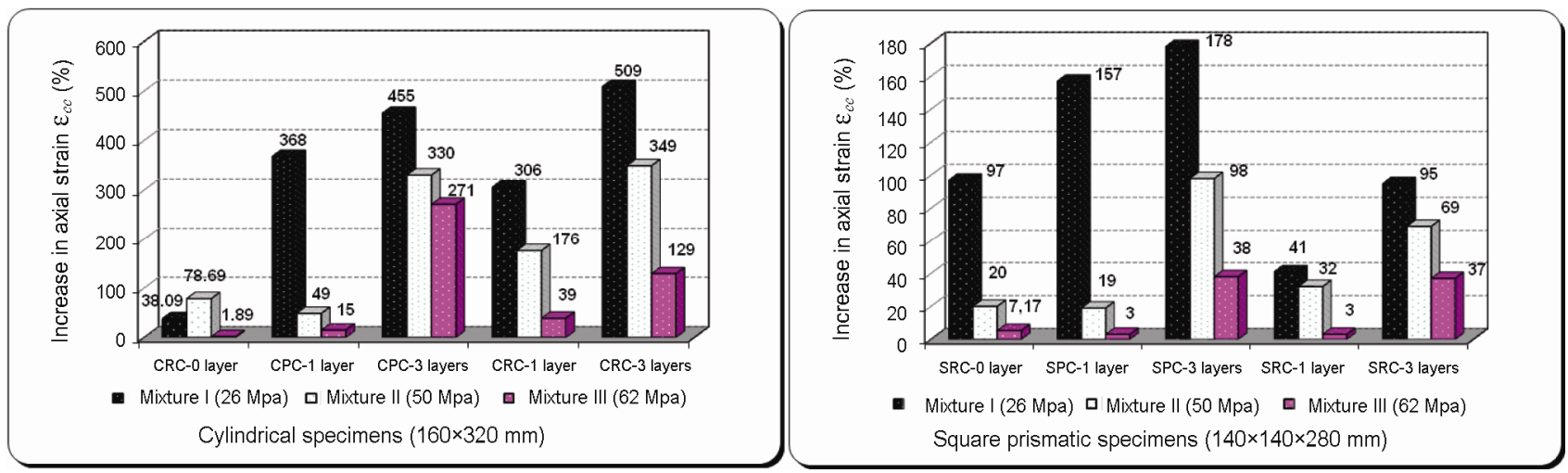

Fig. 7. Effect of unconfined strength of concrete on peak strains

$\mathrm{RC}$ columns confined with one and three layers of CFRP wrap. It is evident that as the unconfined concrete strength increases, the confinement effectiveness decreases. The FRP-wrapped cylinders with the least $f_{c o}$ $(26 \mathrm{MPa})$ show the maximum increases in confined strength $f_{c c}^{\prime}$. Figure 7 shows the effect of $f_{c o}$ on the peak strain $\varepsilon_{c c}$ of the confined concrete. Test results clearly showed that the confinement effectiveness reduces with an increase in the unconfined concrete strength for both circular and square columns and strength enhancement was more significant for circular columns than for square ones. This is due to the concentration of stresses at the corner of the square section and consequently to the lower confining pressure and smaller effective confined concrete core area.

Compared to the FRP-confinement-effectiveness, the confinement provided by the minimum transverse reinforcing steel required by Eurocode 2 led to a limited enhancement in both compressive strength and axial strain with respect to plain concrete specimens. With the exception of SRCI.0L specimens, where its presence contributed to a significant increase in the prism load carrying capacity and ductility as shown in Figures 6 and 7.

\subsection{Stress-strain response}

Representative stress-strain curves for each series of tested CFRP-wrapped specimens are reported in Figure 8 for normal-strength concrete (26 MPa), Figure 9 for mediumstrength concrete $(50 \mathrm{MPa})$ and in Figure 10 for highstrength concrete $(62 \mathrm{MPa})$. These figures give the axial stress versus the axial and lateral strains for circular and square specimens with zero, one and three layers of CFRP wrap. It can be clearly noticed that both the stress and strain at failure for the confined specimens were higher than those for unconfined ones. These figures also show how the ductility of the concrete specimens was affected by the increase of the degree of confinement.

The obtained stress-strain curves which characterise the CFRP confined concrete are mostly bilinear. The first zone is essentially a linear response governed by the stiffness of the unconfined concrete, which indicates that no confinement is activated in the CFRP wraps since the lateral strains in the concrete are very small. The strengthening effect of the CFRP layers begins only after the concrete has reached the peak strength of the unconfined concrete: transversal strains in the concrete activate the FRP jacket. In this region, little increases of load produce large lateral expansions, and consequently a higher confining pressure. In the case of circular sections, the section is fully confined, therefore the second slope is positive, showing the capacity of confining pressure to limit the effects of the deteriorated concrete core, which allows reaching higher stresses. With this type of stressstrain curves (the increasing type), both the compressive strength and the ultimate strain are reached at the same point and are significantly enhanced. Instead in the cases of square sections (sharp edges) with a small amount of FRP, the peak stress is similar to that of unconfined concrete, indicating the fact that the confining action is mostly limited at the corners, producing a confining pressure not sufficient to overcome the effect of concrete degrada- 
tion. Otherwise with low levels of confinement (one CFRP layer), the second part of the bilinear curve shifts from strain hardening to a flat plateau, and eventually to a sudden strain softening with a drastically reduced ductility.

From the trends shown in Figures 8, 9 and 10, it is clear that, unlike normal strength concrete, in medium- to high- strength concrete, confining the specimens with one CFRP layer does not significantly change the stress-strain behaviour of confined concrete from that of unconfined concrete except for a limited increase in compressive strength. In that case, the stress-strain curve terminates at a stress $f_{c u}^{\prime}$ (stress in concrete at the ultimate strain) $<f^{\prime}{ }_{c o}$, the specimen is said to be insufficiently confined. Such case should not be allowed in design.
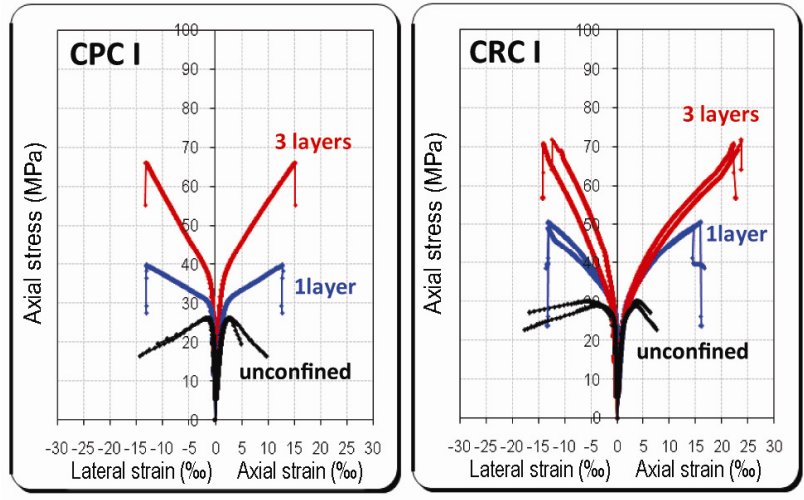

\subsection{Failure modes}

Figure 11 illustrates the failure modes for circular and square columns wrapped with CFRP sheets. All the CFRP-wrapped cylinders failed by the rupture of the FRP jacket due to hoop tension. The CFRP-confined specimens failed in a sudden and explosive manner and were only preceded by some snapping sounds. Many hoop sections formed as the CFRP ruptured. These hoops were either concentrated in the central zone of the specimen or distributed over the entire height. The wider the hoop, the greater the section of concrete that remained attached to the inside faces of the delaminated CFRP. Regarding confined concrete prisms, failure initiated at or near a corner, because of the high stress concentration at these
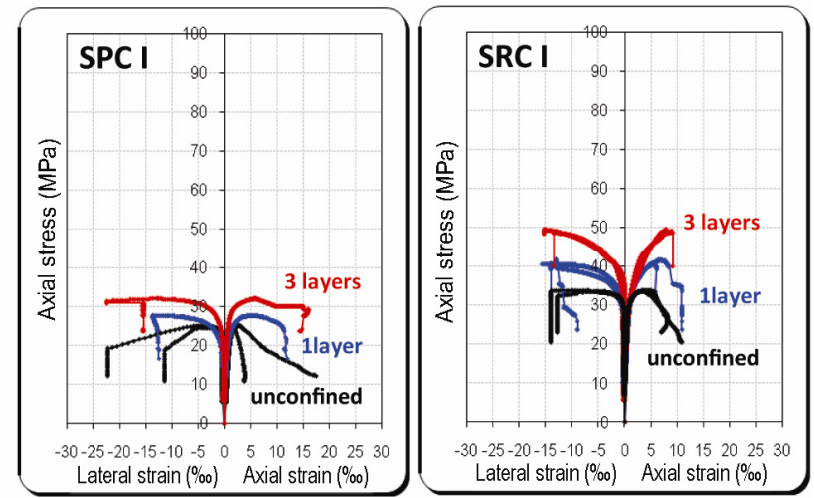

Fig. 8. Experimental stress strain curves of normal-strength concrete specimens $\left(f_{c o}^{\prime}=26 \mathrm{MPa}\right)$
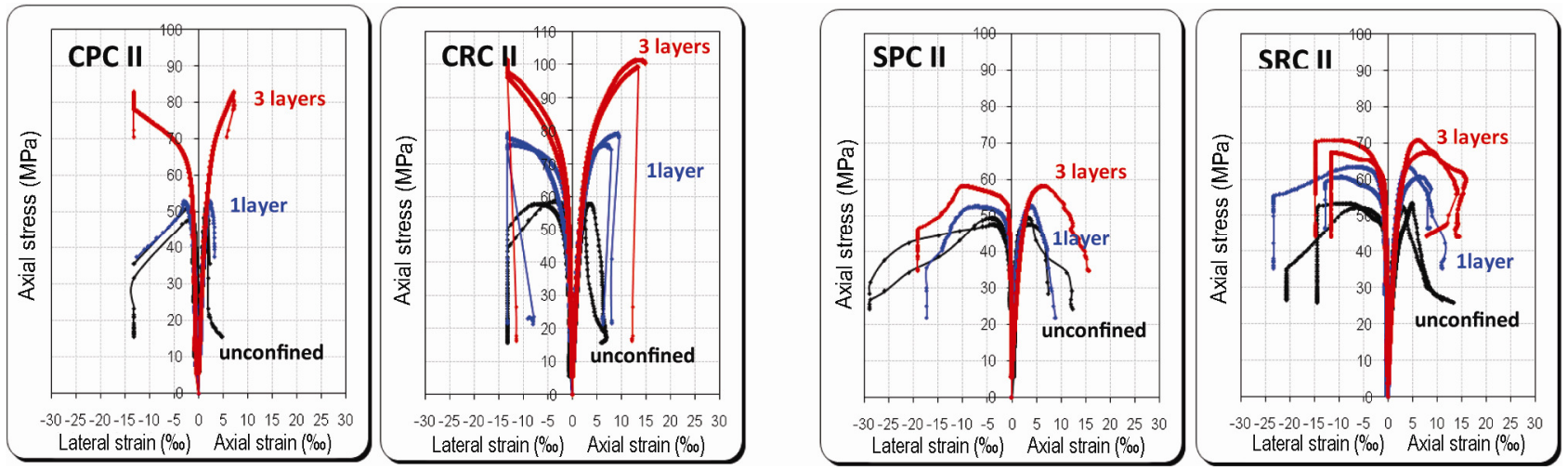

Fig. 9. Experimental stress strain curves of medium-strength concrete specimens $\left(f^{\prime}{ }_{c o}=50 \mathrm{MPa}\right)$
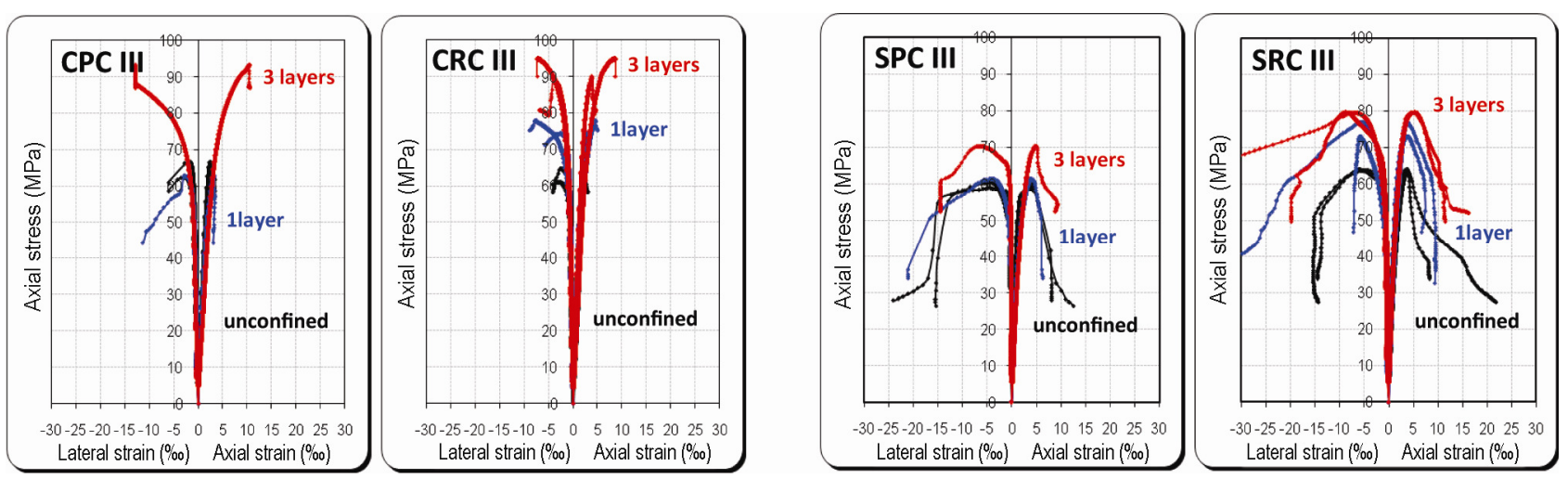

Fig. 10. Experimental stress strain curves of high-strength concrete specimens $\left(f^{\prime}{ }_{c o}=62 \mathrm{MPa}\right)$ 


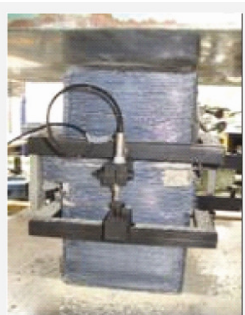

SRCI.1L.1

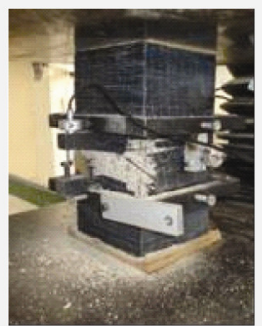

SRCII.1L.1

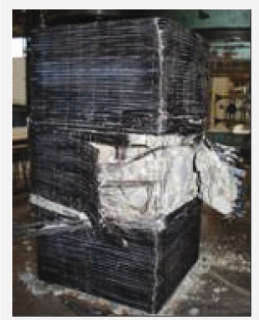

SRCIII.1L.1

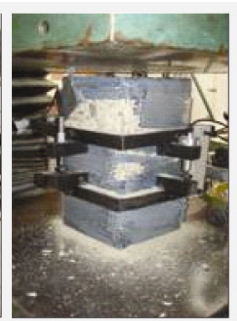

SRCI.3L.1

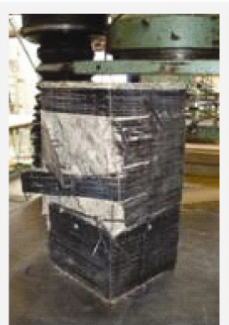

SRCII.3L.1

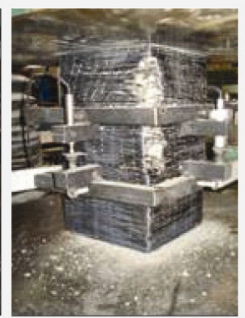

SRCIII.3L.1

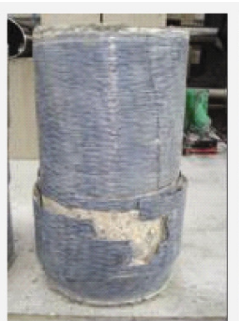

CRCI.1L.1

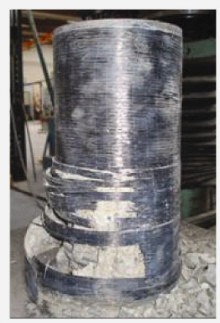

CRCII.1L.1

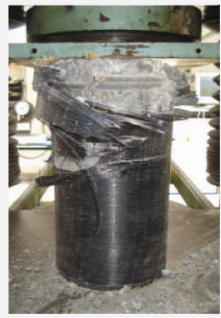

CRCIII.1L. 1

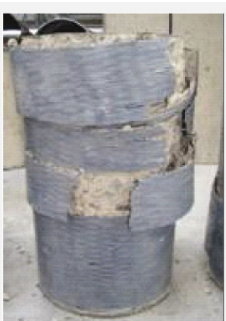

CRCI.3L.1

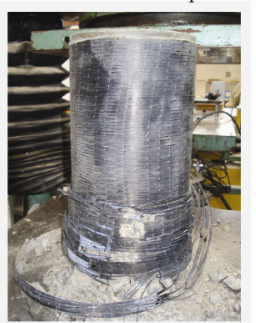

CRCII.3L.1

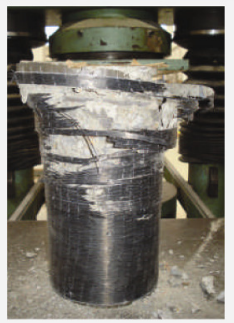

CRCIII.3L.1

Fig. 11. Typical failure modes for the tested specimens

locations. Collapse occurred almost without advance warning by sudden rupture of the composite wrap. For all confined specimens, delamination was not observed at the overlap location of the jacket, which confirmed the adequate stress transfer over the splice.

\section{Model of FRP-confined concrete}

\subsection{Circular columns}

\subsubsection{Compressive strength of FRP-confined concrete}

Various models for confinement of concrete with FRP have been developed. The majority of these models were performed on plain concrete specimen tests. A limited number of tests have been reported in the literature on the axial compressive strength and strain of reinforcedconcrete specimens confined with FRP. Most of the existing strength models for FRP-confined concrete adopted the concept of Richart et al. (1929), in which the strength at failure for concrete confined by hydrostatic fluid pressure takes the following form:

$$
f^{\prime}{ }_{c c}=f^{\prime}{ }_{c o}+k_{1} \cdot f_{l},
$$

where: $f_{c c}^{\prime}$ and $f^{\prime}{ }_{c o}$ are the compressive strength of confined and the unconfined concrete respectively; $f_{l}$ is the lateral confining pressure; and $k_{1}$ is the confinement effectiveness coefficient. In applying their model to steelconfined concrete, Richart et al. (1929) assumed that $k_{1}$ is a constant equal to 4.1. However, several studies revealed that existing models for the axial compressive strength of steel-confined concrete are un-conservative and cannot be used for FRP-confined concrete (Mirmiran, Shahawy 1997; Samaan et al. 1998; Saafi et al. 1999; Spoelstra, Monti 1999; Teng et al. 2002; Xiao; Wu 2003; Matthys et al. 2005). Many authors have raised towards the steelbased confinement models the objection that they do not account for the profound difference in uniaxial tensile stress-strain behaviour between steel and FRP. According to these authors, while the assumption of constant confining pressure is still realistic in the case of steel confinement in the yield phase, it cannot be extended to FRP materials which do not exhibit any yielding and therefore apply on the concrete core a continuously increasing inward pressure. However, a number of strength models have been proposed specifically for FRP-confined concrete which employ Eqn (4) with modified expressions for $k_{1}$ (e.g. Mirmiran, Shahawy 1997; Karbhari, Gao 1997; Samaan et al. 1998; Saafi et al. 1999; Miyauchi et al. 1999; Toutanji 1999; Thériault, Neale 2000; Lam, Teng 2002, 2003a; Xiao, Wu 2003; Matthys et al. 2005; Wu et al. 2006; Ilki 2006; Berthet et al. 2006; Teng et al. 2007; Jiang, Teng 2007). Most of these models used a constant value for $k_{1}$ (between 2 and 3.5) indicating that the experimental data available in the literature show a linear relationship between the strength of confined concrete $f^{\prime}{ }_{c c}$ and the lateral confining pressure $f_{l}$ (Miyauchi et al. 1999; Thériault, Neale 2000; Berthet et al. 2006; Wu et al. 2006; Teng et al. 2007; Jiang, Teng 2007; Lam, Teng 2002, 2003a; Ilki 2006). Other researchers expressed $k_{1}$ in nonlinear form in terms of $f_{l} / f^{\prime}$ co or $f_{l}$ 
(Mirmiran, Shahawy 1997; Karbhari, Gao 1997; Samaan et al. 1998; Saafi et al. 1999; Toutanji 1999; Xiao, Wu 2003; Matthys et al. 2005).

\section{FRP circumferential failure strain}

According to the obtained test results, cylinder failure occurs before the FRP reached the ultimate strain capacities $\varepsilon_{f u}$. So the failure occurs prematurely and the circumferential failure strain was lower than the ultimate strain obtained from standard tensile testing of the FRP composite. This phenomenon considerably affects the accuracy of the existing models for FRP-confined concrete. Referring to Table 4, for example, the rupture of the low-strength-cylinder IRCC.2.3L corresponded to a maximum composite extension (circumferential failure strain) $\varepsilon_{h, \text { rup }}$ of $12.42 \%$, which is lower than the ultimate composite strain $\varepsilon_{f u}(14 \%$ o) as it represents approx. $88 \%$ of it. This reduction in the strain of the FRP composites can be attributed to several causes as reported in related literature (Matthys et al. 2005; Lam, Teng 2003a; Yang et al. 2001):

- The curved shape of the composite wrap or misalignment of fibres may reduce the FRP axial strength;

- Near failure, concrete is internally cracked resulting in non-homogeneous deformations. Due to this nonhomogeneous deformations and high loads applied on the cracked concrete, local stress concentrations may occur in the FRP reinforcement.

\section{Effective FRP strain coefficient}

In existing models for FRP-confined concrete, it is commonly assumed that the FRP ruptures when the hoop stress in the FRP jacket reaches its tensile strength from either flat coupon tests which is herein referred to as the FRP material tensile strength. This assumption is the

Table 4. Average hoop rupture strain ratios (circular specimens)

\begin{tabular}{clccc}
\hline $\begin{array}{c}\text { Concrete } \\
\text { mixture }\end{array}$ & $\begin{array}{c}\text { Specimen } \\
\text { code }\end{array}$ & $\varepsilon_{f u}(\%)$ & $\varepsilon_{\text {h.rup. }}(\%)$ & $\varepsilon_{h . r u p .} / \varepsilon_{f u}$ \\
\hline & CRCI.1L.1 & 14 & 13.15 & 0.939 \\
& CRCI.1L.2 & 14 & 13.16 & 0.940 \\
I (26 MPa) $)$ & CRCI.3L.1 & 14 & 14.06 & 1.004 \\
& CRCI.3L.2 & 14 & 12.42 & 0.887 \\
\cline { 2 - 5 } & CPCI.1L.1 & 14 & 13.12 & 0.937 \\
& CPCI.3L.1 & 14 & 13.18 & 0.941 \\
\hline & CRCII.1L.1 & 14 & 13.17 & 0.940 \\
& CRCII.1L.2 & 14 & 13.16 & 0.940 \\
II (50 MPa) & CRCII.3L.1 & 14 & 13.20 & 0.942 \\
& CRCII.3L.2 & 14 & 13.17 & 0.940 \\
\cline { 2 - 5 } & CPCII.1L.1 & 14 & 2.90 & 0.207 \\
& CPCII.3L. 1 & 14 & 13.15 & 0.939 \\
\hline & CRCIII.1L.1 & 14 & 7.79 & 0.556 \\
& CRCIII.1L.2 & 14 & 2.61 & 0.186 \\
III (62 MPa) & CRCIII.3L.1 & 14 & 4.10 & 0.292 \\
& CRCIII.3L.2 & 14 & 7.15 & 0.510 \\
\cline { 2 - 5 } & CPCIII.1L.1 & 14 & 2.46 & 0.175 \\
& CPCIII.3L.1 & 14 & 12.89 & 0.920 \\
\hline & & & & \\
\hline
\end{tabular}

basis for calculating the maximum confining pressure $f_{l}$ (the confining pressure reached when the FRP ruptures) given by Eqn (1). The confinement ratio of an FRPconfined specimen is defined as the ratio of the maximum confining pressure to the unconfined concrete strength $\left(f_{l} / f^{\prime}{ }_{c o}\right)$.

However, experimental results show that, the FRP material tensile strength was not reached at the rupture of FRP in FRP-confined concrete. Table 4 provides the average ratios between the measured circumferential strain at FRP rupture $\left(\varepsilon_{h, \text { rup }}\right)$ and the ultimate tensile strain of the FRP material $\left(\varepsilon_{f u}\right)$. It is seen that, when all circular specimens of the present study are considered together, the average ratio $\left(\varepsilon_{h, \text { rup }} / \varepsilon_{f u}\right)$ has a value closer to 0.73 and is referred to, in this paper, as the effective FRP strain coefficient $\eta$. Thus, the maximum confining pressure given by Eqn (1) can be considered as a nominal value. The effective maximum lateral confining pressure is given by:

$$
f_{l, e f f}=\frac{2 t_{f r p} E_{f r p} \varepsilon_{h, r u p}}{d}=\frac{2 t_{f r p} E_{f r p} \eta \varepsilon_{f u}}{d}=\eta f_{l} .
$$

Table 5 indicates that the assumption that the FRP ruptures when the stress in the jacket reaches the FRP material tensile strength is invalid for concrete confined by FRP wraps.

\section{Proposed equation}

A simple equation is proposed to predict the peak strength of FRP-confined concrete of different unconfined strengths based on regression of test data reported in Table 5. Figure 12 shows the relation between actual confinement ratio $f_{l, \text { eff }} f_{c o}^{\prime}$ and the strengthening ratio $f^{\prime}{ }^{\prime} d f^{\prime}{ }_{c o}$ for the cylinders of the test series. It can be seen that, strengthening ratio is proportional to the volumetric ratio and the strength of FRP (in terms of effective lateral confining pressure $f_{l, e f f}$ and is inversely proportional to unconfined concrete strength. Therefore the relationship may be approximated by a linear function. The trend line of these test data can be closely approximated using the following equation:

$$
\frac{f^{\prime}{ }_{c c}}{f^{\prime}{ }_{c o}}=1+2.20 \frac{f_{l, e f f}}{f^{\prime}{ }_{c o}}
$$

Using a reduction factor $\eta$ of 0.73 with the replacement of $f_{l, \text { eff }}$ by $f_{l}$ into Eqn (6) the ultimate axial compressive strength of FRP-confined concrete takes the form:

$$
\frac{f^{\prime}{ }_{c c}}{f^{\prime}{ }_{c o}}=1+1.60 \frac{f_{l}}{f^{\prime}{ }_{c o}}
$$

Figure 13 is a plot of the strengthening ratio $f^{\prime}{ }^{\prime} / f^{\prime}{ }^{\prime} c$ against the confinement ratio $f_{l} f^{\prime}{ }^{\prime}$. The trend line of this figure shows a much greater average confinement effectiveness coefficient $k_{1}$. This can be attributed to the effect of the effective lateral confining pressure.

\subsubsection{Axial strain of FRP-confined concrete}

Early investigation showed that for steel confined concrete, the axial compressive strain $\varepsilon_{c c}$ at the peak axial 
stress can be related to the lateral confining pressure (Richart et al. 1929) by:

$$
\varepsilon_{c c}=\varepsilon_{c o}\left(1+k_{2} \frac{f_{l}}{f^{\prime}{ }_{c o}}\right),
$$

where $\varepsilon_{c o}$ is the axial strain of the unconfined concrete at its peak stress and $k_{2}$ is the strain enhancement coefficient. Richart et al. (1929) suggested $k_{2}=5 k_{1}$ for steelconfined concrete. For FRP-confined concrete, many studies suggested that ultimate axial strain can also be related to the lateral confining pressure (e.g. Karbhari, Gao 1997; Shehata et al. 2002; De Lorenzis, Tepfers 2003; Lam, Teng 2003a; Matthys et al. 2005; Ilki 2006; Vintzileou, Panagiotidou 2008; Jiang, Teng 2007).

In literature, some methods for predicting the ultimate strain of FRP-confined concrete cylinders have been proposed. Existing models can be classified into three categories as follows:

a. Steel-based confined models (e.g. Saadatmanesh et al. 1994; Fardis, Khalili 1982), Saadatmanesh et al. (1994) assumed that:

$$
\frac{\varepsilon_{c c}}{\varepsilon_{c o}}=1+5\left(\frac{f^{\prime}{ }_{c c}}{f^{\prime}{ }_{c o}}-1\right)
$$

where $\varepsilon_{c o}$ is the strain in peak stress of unconfined concrete and $\varepsilon_{c c}$ is axial strain at peak stress of the FRPconfined concrete.

b. Empirical or analytical models (e.g. Samaan et al. 1998; Toutanji 1999; Miyauchi et al. 1999; Teng et al. 2002; Siddhawartha et al. 2005; Jiang, Teng 2007; Rousakis, Karabinis 2008; Vintzileou, Panagiotidou 2008), Teng et al. (2002) proposed:
- For CFRP wrapped concrete:

$$
\frac{\varepsilon_{c c}}{\varepsilon_{c o}}=2+15\left(\frac{f_{l}}{f^{\prime}{ }_{c o}}\right)
$$

- For design use:

$$
\frac{\varepsilon_{c c}}{\varepsilon_{c o}}=1.75+10\left(\frac{f_{l}}{f^{\prime} c o}\right) .
$$

c. Recently, some models for predicting the axial stress and strain of FRP-confined concrete were suggested based on numerical method or plasticity analysis (e.g. Shahawy et al. 2000; Karabinis, Rousakis 2001; Moran, Pantelides 2002; Becque et al. 2003; Malvar et al. 2004), whereas these models are often not suitable for direct use in design.

\section{Proposed equation}

Figure 14 shows the relation between the strain enhancement ratio and the actual confinement ratio of the present test data. A linear relationship clearly exists. This diagram indicates that the axial strain of FRP-confined concrete can be related linearly to the actual confinement ratio. Based on regression of test data reported in Table 5, the axial strain of CFRP-wrapped concrete can be approximated by the following expression:

\begin{tabular}{|c|c|c|c|c|c|c|c|c|c|c|c|c|c|c|c|c|}
\hline $\begin{array}{l}\text { Concrete } \\
\text { mixture }\end{array}$ & $\begin{array}{l}\text { Specimen } \\
\text { code }\end{array}$ & $\sum_{i}^{\stackrel{\Xi}{0}}$ & ఏ్ & हैं & $\frac{\widehat{\varrho}}{\omega}$ & 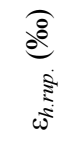 & $\underset{\mho}{\stackrel{\Xi \Xi}{\Xi}}$ & 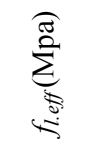 & $\sum_{=}^{\stackrel{\Xi}{ٍ}}$ & $\sum_{i}^{8}$ & $\underbrace{-8}_{\stackrel{8}{5}}$ & $\sum_{i}^{\stackrel{\mathbb{Z}}{2}}$ & $\begin{array}{l}i^{8} \\
i^{8}\end{array}$ & $\underbrace{\stackrel{8}{0}}_{\omega}$ & $\underbrace{\frac{\partial}{\partial}}_{\tilde{\omega}}$ & $\frac{\omega^{8}}{\tilde{\omega}}$ \\
\hline \multirow{6}{*}{ I (26 Mpa) } & CRCI.1L.1 & 29.51 & 1 & 34 & 14 & 13.15 & 160 & 5.588 & 5.950 & 0.201 & 0.189 & 50.59 & 1.714 & 3.77 & 15.93 & 4.225 \\
\hline & CRCI.1L.2 & 29.51 & 1 & 34 & 14 & 13.16 & 160 & 5.593 & 5.950 & 0.201 & 0.189 & 49.17 & 1.666 & 3.77 & 14.75 & 3.912 \\
\hline & CRCI.3L.1 & 29.51 & 3 & 34 & 14 & 14.06 & 160 & 17.926 & 17.850 & 0.604 & 0.607 & 70.83 & 2.400 & 3.77 & 22.22 & 5.893 \\
\hline & CRCI.3L .2 & 29.51 & 3 & 34 & 14 & 12.42 & 160 & 15.835 & 17.850 & 0.604 & 0.536 & 71.88 & 2.435 & 3.77 & 23.74 & 6.297 \\
\hline & CPCI.1L.1 & 25.93 & 1 & 34 & 14 & 13.12 & 160 & 5.576 & 5.950 & 0.229 & 0.215 & 39.63 & 1.528 & 2.73 & 12.78 & 4.681 \\
\hline & CPCI.3L ${ }_{\cdot 1}$ & 25.93 & 3 & 34 & 14 & 13.18 & 160 & 16.804 & 17.850 & 0.688 & 0.648 & 66.14 & 2.550 & 2.73 & 15.16 & 5.553 \\
\hline \multirow{6}{*}{ II (50 Mpa) } & CRCII.1L.1 & 58.24 & 1 & 34 & 14 & 13.17 & 160 & 5.597 & 5.950 & 0.102 & 0.096 & 75.84 & 1.302 & 3.02 & 7.37 & 2.440 \\
\hline & CRCII.1L.2 & 58.24 & 1 & 34 & 14 & 13.16 & 160 & 5.593 & 5.950 & 0.102 & 0.096 & 79.18 & 1.359 & 3.02 & 9.35 & 3.096 \\
\hline & CRCII.3L.1 & 58.24 & 3 & 34 & 14 & 13.20 & 160 & 16.830 & 17.850 & 0.306 & 0.288 & 101.48 & 1.742 & 3.02 & 13.72 & 4.543 \\
\hline & CRCII.3L.2 & 58.24 & 3 & 34 & 14 & 13.17 & 160 & 16.791 & 17.850 & 0.306 & 0.288 & 99.35 & 1.705 & 3.02 & 13.44 & 4.450 \\
\hline & CPCII.1L.1 & 49.46 & 1 & 34 & 14 & 2.90 & 160 & 1.232 & 5.950 & 0.120 & 0.024 & 52.75 & 1.066 & 1.69 & 2.52 & 1.491 \\
\hline & CPCII.3L ${ }_{\cdot 1}$ & 49.46 & 3 & 34 & 14 & 13.15 & 160 & 16.766 & 17.850 & 0.360 & 0.338 & 82.91 & 1.676 & 1.69 & 7.27 & 4.301 \\
\hline \multirow{6}{*}{ III (62 Mpa) } & CRCIII.1L.1 & 63.01 & 1 & 34 & 14 & 7.79 & 160 & 3.310 & 5.950 & 0.094 & 0.052 & 77.99 & 1.237 & 2.69 & 4.59 & 1.706 \\
\hline & CRCIII.1L.2 & 63.01 & 1 & 34 & 14 & 2.61 & 160 & 1.109 & 5.950 & 0.094 & 0.017 & 74.43 & 1.181 & 2.69 & 2.91 & 1.081 \\
\hline & CRCIII.3L.1 & 63.01 & 3 & 34 & 14 & 4.10 & 160 & 5.227 & 17.850 & 0.283 & 0.082 & 94.92 & 1.506 & 2.69 & 3.87 & 1.438 \\
\hline & CRCIII.3L.2 & 63.01 & 3 & 34 & 14 & 7.15 & 160 & 9.116 & 17.850 & 0.283 & 0.144 & 94.71 & 1.503 & 2.69 & 8.49 & 3.156 \\
\hline & CPCIII.1L.1 & 61.81 & 1 & 34 & 14 & 2.46 & 160 & 1.045 & 5.950 & 0.096 & 0.016 & 62.68 & 1.014 & 2.64 & 3.04 & 1.151 \\
\hline & CPCIII.3L.1 & 61.81 & 3 & 34 & 14 & 12.89 & 160 & 16.434 & 17.850 & 0.288 & 0.265 & 93.19 & 1.507 & 2.64 & 9.80 & 3.711 \\
\hline
\end{tabular}

$$
\frac{\varepsilon_{c c}}{\varepsilon_{c o}}=2+7.6\left(\frac{f_{l, e f f}}{f_{c o}^{\prime}}\right) \text {. }
$$

Table 5. Data and results of CFRP wrapped cylinders 
Table 6. Comparison of experimental and predicted results: compressive strength

\begin{tabular}{|c|c|c|c|c|c|c|c|c|c|c|c|}
\hline Specimen code & FRP Type & $\begin{array}{c}f_{c o}^{\prime} \\
(\mathrm{Mpa})\end{array}$ & $\begin{array}{c}E_{f r p} \\
(\mathrm{Gpa})\end{array}$ & $\begin{array}{c}\varepsilon_{f u} \\
(\%)\end{array}$ & $\begin{array}{c}t_{f r p} \\
(\mathrm{~mm})\end{array}$ & $\begin{array}{c}d \\
(\mathrm{~mm})\end{array}$ & $\begin{array}{c}f_{l} \\
(\mathrm{Mpa}) \\
\end{array}$ & $k_{1}$ & $\begin{array}{r}f_{\text {cc.theo }}^{\prime} \\
(\mathrm{Mpa})\end{array}$ & $\begin{array}{l}f_{c c, \exp }^{\prime} \\
(\mathrm{Mpa})\end{array}$ & $f_{\text {cc.theo. }}^{\prime} / f_{\text {cc.exp }}^{\prime}$ \\
\hline \multicolumn{12}{|c|}{ Matthys et al. (2005) } \\
\hline $\mathrm{k} 2$ & CFRP & 32 & 198 & 11.9 & 0.585 & 400 & 6.891 & 1.6 & 43.027 & 54.30 & 0.792 \\
\hline $\mathrm{k} 8$ & HFRP & 32 & 120 & 9.6 & 0.492 & 400 & 2.833 & 1.6 & 36.534 & 44.40 & 0.822 \\
\hline \multicolumn{12}{|l|}{ Ilki et al. (2003) } \\
\hline CYL-5-1 & CFRP & 6.2 & 230 & 15 & 0.825 & 150 & 37.950 & 1.6 & 66.920 & 87.70 & 0.763 \\
\hline CYL-5-2 & CFRP & 6.2 & 230 & 15 & 0.825 & 150 & 37.950 & 1.6 & 66.920 & 82.70 & 0.809 \\
\hline \multicolumn{12}{|l|}{ Lam et al. (2006) } \\
\hline CI-M1 & CFRP & 41.1 & 250 & 15.2 & 0.165 & 152 & 8.250 & 1.6 & 54.300 & 52.60 & 1.032 \\
\hline CI-M3 & CFRP & 41.1 & 250 & 15.2 & 0.165 & 152 & 8.250 & 1.6 & 54.300 & 55.40 & 0.980 \\
\hline CII-M3 & CFRP & 38.9 & 247 & 15.2 & 0.33 & 152 & 16.302 & 1.6 & 64.983 & 65.80 & 0.987 \\
\hline \multicolumn{12}{|c|}{ Jiang and Teng (2007) } \\
\hline 36 & CFRP & 38 & 240.7 & 15 & 1.02 & 152 & 48.456 & 1.6 & 115.530 & 129 & 0.895 \\
\hline 39 & CFRP & 38 & 240.7 & 15 & 1.36 & 152 & 64.608 & 1.6 & 141.374 & 158.5 & 0.891 \\
\hline 40 & CFRP & 37.7 & 260 & 15 & 0.11 & 152 & 5.644 & 1.6 & 46.731 & 48.50 & 0.963 \\
\hline 41 & CFRP & 37.7 & 260 & 15 & 0.11 & 152 & 5.644 & 1.6 & 46.731 & 50.30 & 0.929 \\
\hline 42 & CFRP & 44.2 & 260 & 15 & 0.11 & 152 & 5.644 & 1.6 & 53.231 & 48.10 & 1.106 \\
\hline 43 & CFRP & 44.2 & 260 & 15 & 0.11 & 152 & 5.644 & 1.6 & 53.231 & 51.10 & 1.041 \\
\hline 45 & CFRP & 44.2 & 260 & 15 & 0.22 & 152 & 11.289 & 1.6 & 62.263 & 62.90 & 0.989 \\
\hline 46 & CFRP & 47.6 & 250.5 & 15 & 0.33 & 152 & 16.315 & 1.6 & 73.704 & 82.70 & 0.891 \\
\hline \multirow{3}{*}{\multicolumn{7}{|c|}{$\begin{array}{l}\text { CFRP: carbon fibre-reinforced polymer; } \\
\text { HFRP: hybrid fibre-reinforced polymer. }\end{array}$}} & \multicolumn{4}{|c|}{ Average: } & 0.926 \\
\hline & & & & & & & \multicolumn{4}{|c|}{ Standard deviation: } & 0.101 \\
\hline & & & & & & & \multicolumn{5}{|c|}{ Coefficient of variation $(\%)$ : } \\
\hline
\end{tabular}

Table 7. Comparison of experimental and predicted results: axial strain

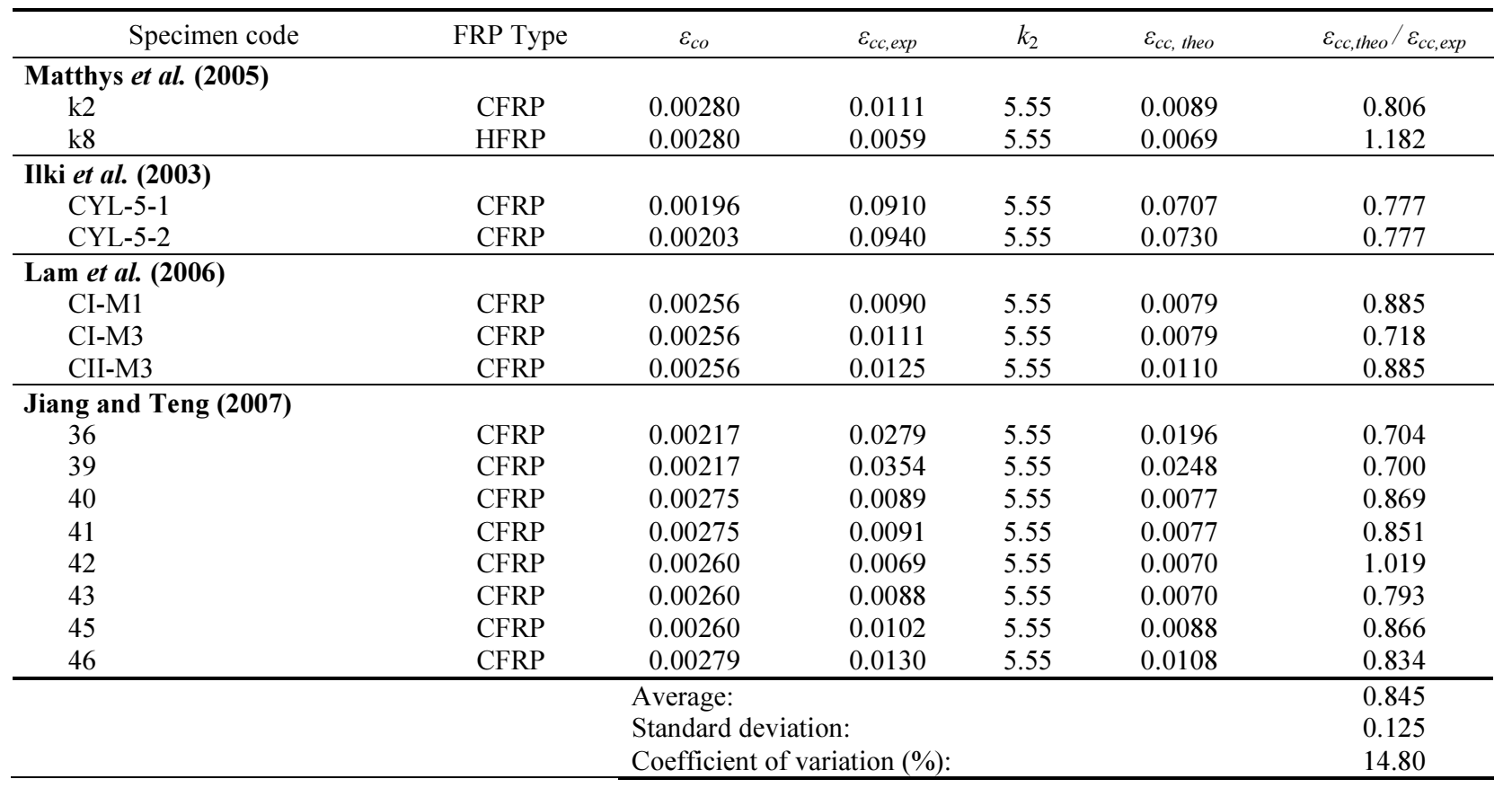

Replacing $f_{l, \text { eff }}$ by $f_{l}$ into Eqn (12) the axial strain of FRP-confined concrete takes the form:

$$
\frac{\varepsilon_{c c}}{\varepsilon_{c o}}=2+5.55\left(\frac{f_{l}}{f_{c o}^{\prime}}\right) \text {. }
$$

Given that $\varepsilon_{c c}$ for concrete sufficiently confined by FRP is the ultimate strain $\varepsilon_{c u}$.

\subsubsection{Validation of the proposed model}

Using the model provided above, the compressive strength and axial strain of FRP-confined specimens collected from other studies (Ilki et al. 2003; Matthys et al. 2005; Lam et al. 2006; Jiang, Teng 2007) were predicted as shown in Table 6 and 7 which clearly exhibits excellent agreement between the experimental and predicted results. The present model is more accurate in predicting the compressive strength but less accurate in predicting the axial strain. 


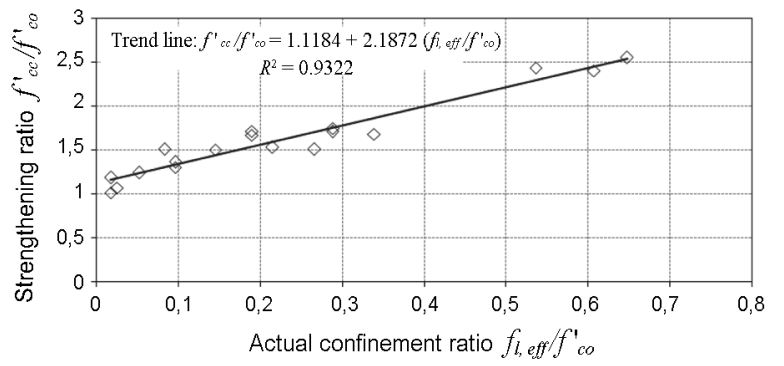

Fig. 12. Strengthening ratio vs. actual confinement ratio

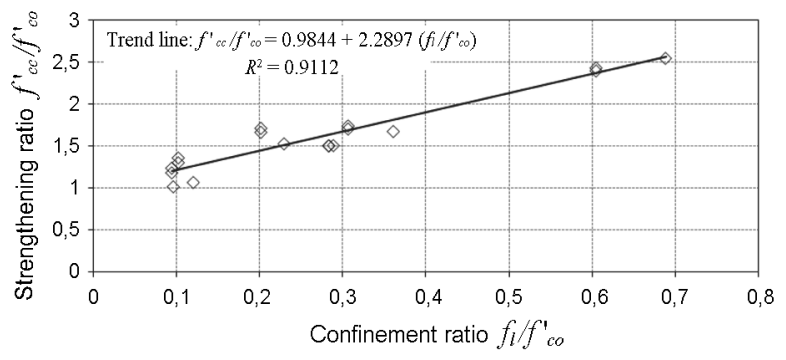

Fig. 13. Strengthening ratio vs. confinement ratio

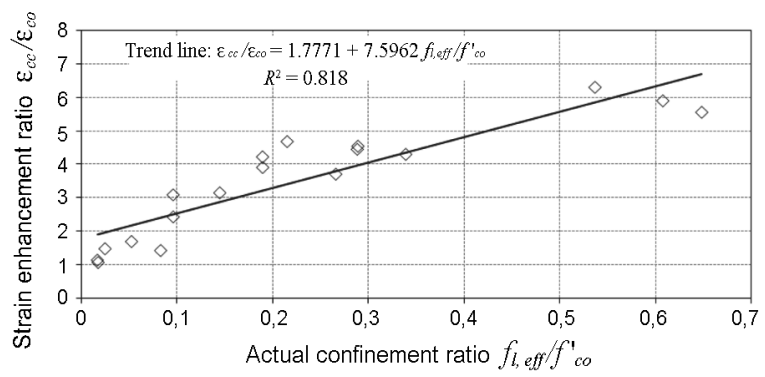

Fig. 14. Strain enhancement ratio vs. actual confinement ratio
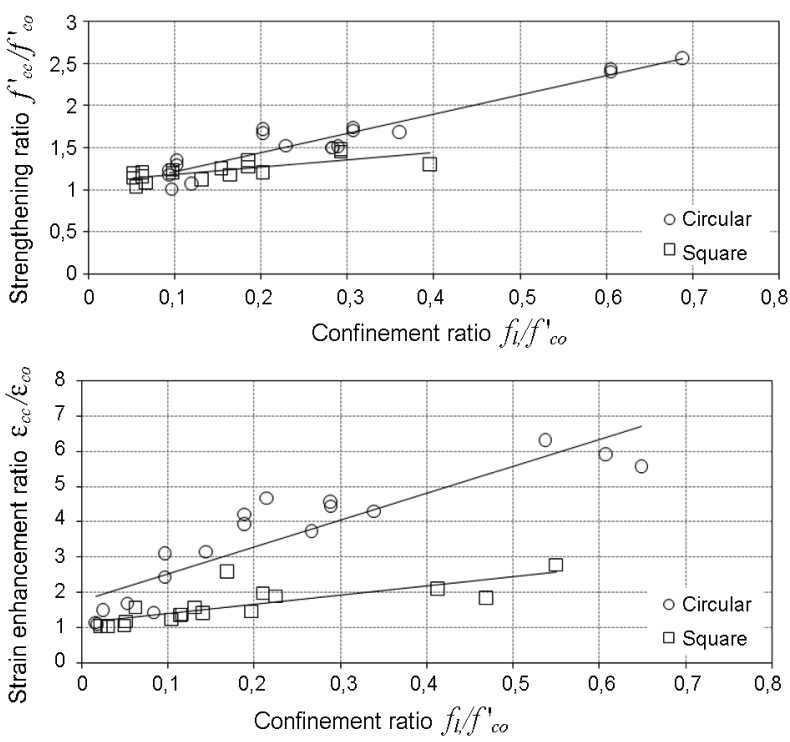

Fig. 15. Strengthening ratio vs. confinement ratio and strain enhancement ratio vs. confinement ratio for the test results of this work

In Figure 15 the strengthening ratio-confinement ratio and the strain enhancement ratio-confinement ratio plots for the test results of this work (circular and square specimens) are shown, together with their respective linear regressions. From these figures, it can be seen that the axial confined compressive strength and the corresponding axial strain, approximately, increase linearly with the increase in confining lateral pressure for all types of section geometry. There is also a great distinction between the tendency of the results obtained for circular columns and those for square ones.

\subsection{Square columns}

\subsubsection{Compressive strength}

\section{The effective lateral confining pressure}

The effective lateral confining pressure $f_{l}^{\prime}$ can be defined as a function of the shape through the use of a confinement effectiveness coefficient $k_{e}$ as:

$$
f_{l}^{\prime}=k_{e} f_{l},
$$

were $f_{l}$ is the lateral confining pressure provided by a FRP jacket and can be evaluated using Eqn (1), with the columns diameter $d$ replaced by the diagonal length of the square section. $f_{l}$ now becomes an equivalent confining pressure provided by the FRP jacket to equivalent circular columns. On the other hand, the effective FRP strain coefficient $\eta$ ' is defined as the ratio of the FRP tensile hoop strain at rupture in the square column tests $\left(\varepsilon_{h, \text { rup }}\right)$ to the ultimate tensile strain from FRP tensile coupon tests $\left(\varepsilon_{f u}\right)$ :

$$
\eta^{\prime}=\frac{\varepsilon_{h, r u p}}{\varepsilon_{f u}} .
$$

The effective FRP strain coefficient represents the degree of participation of the FRP jacket, and the friction between concrete and FRP laminate. Type bond, geometry, FRP jacket thickness, and type of resin affect the effective FRP strain coefficient. From the experimental results (Table 8 ), $\eta$ ' was $68 \%$ on average for square bonded jackets.

Based on these observations, the effective equivalent lateral confining pressure $f_{l}$ for the square section is given by:

- For the square section:

$$
f_{l}=\frac{2 t_{f r p} E_{f r p} \varepsilon_{h, r u p}}{\sqrt{2} b}=\frac{2 t_{f r p} E_{f r p} \eta^{\prime} \varepsilon_{f u}}{\sqrt{2} b} ;
$$

- For square section with round corners:

$f_{l}=\frac{2 t_{f r p} E_{f r p} \varepsilon_{h, r u p}}{\sqrt{2} b-2 R c(\sqrt{2}-1)}=\frac{2 t_{f r p} E_{f r p} \eta^{\prime} \varepsilon_{f u}}{\sqrt{2} b-2 R c(\sqrt{2}-1)}$.

\section{Confinement effectiveness coefficient " $k_{e}$ "}

For the determination of the effectiveness factor $k_{e}$ it can be assumed that, in the case of a circular crosssection, the entire concrete core is effectively confined, while, for the square section there is a reduction in the effectively confined core that can be assumed, analogously with the case of the concrete core confined by trans- 
verse steel stirrups (Mander et al. 1988), in the form of the second-degree parabola with an initial tangent slope of $45^{\circ}$. For a square section wrapped with FRP (Fig. 16) and with corners rounded with a radius Rc, the parabolic arching action is again assumed for the concrete core where the confining pressure is fully developed. Unlike a circular section, for which the concrete core is fully confined, a large part of the cross-section remains unconfined. Based on this observation, it is possible to obtain the area of unconfined concrete $A_{u}$, as follows:

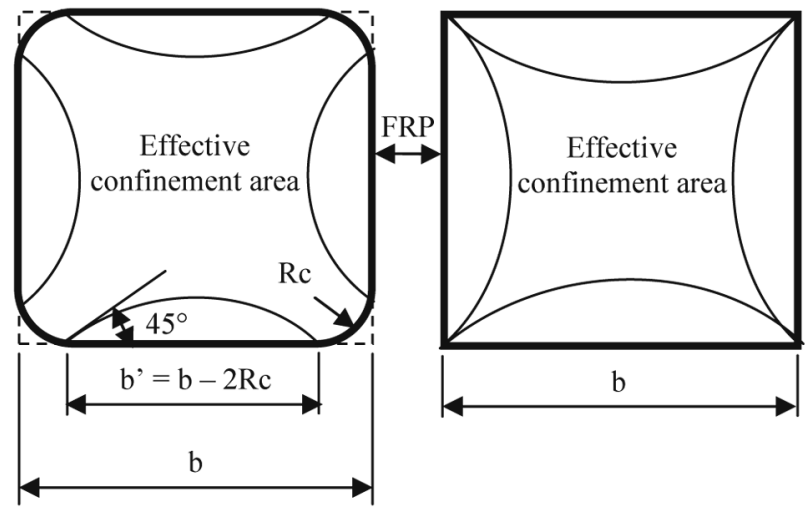

Fig. 16. Effectively confined core for square sections

- For square section:

$$
A_{u}=4\left(\frac{b^{2}}{6}\right)=\frac{2 b^{2}}{3}
$$

- For square section with round corners:

$$
A_{u}=4\left(\frac{b^{\prime 2}}{6}\right)=\frac{2 b^{\prime 2}}{3}
$$

The confinement effectiveness coefficient $k_{e}$ is given by the ratio of the effective confinement area $A_{e}$ to the total area of concrete enclosed by the FRP jacket, $A_{c}$, as follows:

$k_{e}=\frac{A_{e}}{A_{c}}=\frac{\left(A_{c}-A_{u}\right)}{A_{c}}=1-\frac{A_{u}}{\left(A_{g}-A_{s}\right)}==1-\frac{A_{u}}{A_{g}\left(1-\rho_{s c}\right)}$,

where $A_{g}$ is the gross area of column section, and $\rho_{s c}$ is the cross-sectional area ratio of longitudinal steel.

By substituting the expression (17) or (18) into (19), the confinement effectiveness coefficient $k_{e}$ is therefore given by:

- For square section:

$$
k_{e}=1-\frac{2 b^{2}}{3 A_{g}\left(1-\rho_{s c}\right)} ;
$$

- For square section with round corners:

$$
k_{e}=1-\frac{2 b^{\prime 2}}{3 A_{g}\left(1-\rho_{s c}\right)} .
$$

\begin{tabular}{|c|c|c|c|c|c|c|c|c|c|c|c|c|c|c|c|c|}
\hline $\begin{array}{l}\text { Concrete } \\
\text { mixture }\end{array}$ & $\begin{array}{l}\text { Specimen } \\
\text { code }\end{array}$ & 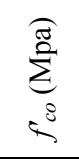 & 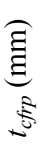 & 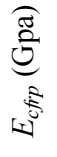 & 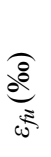 & 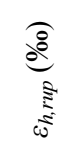 & $\frac{\overparen{\Xi}}{\underset{\Xi}{\Xi}}$ & 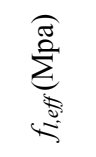 & 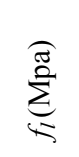 & $\frac{8}{5}$ & $\underbrace{\frac{8}{5}}_{5}$ & 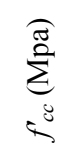 & $\frac{8^{8}}{8^{8}}$ & $\underbrace{\frac{8}{8}}_{\omega^{8}}$ & 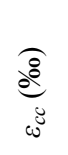 & $\frac{\omega^{8}}{\omega^{\bar{v}}}$ \\
\hline \multirow{6}{*}{ I (26 Mpa) } & SRCI.1L.1 & 33.59 & 1 & 34 & 14 & 10.28 & 197.989 & 3.530 & 3.269 & 0.097 & 0.105 & 40.48 & 1.2051 & 4.29 & 5.36 & 1.249 \\
\hline & SRCI.1L.2 & 33.59 & 1 & 34 & 14 & 12.88 & 197.989 & 4.423 & 3.269 & 0.097 & 0.131 & 41.56 & 1.2373 & 4.29 & 6.80 & 1.585 \\
\hline & SRCI.3L.1 & 33.59 & 3 & 34 & 14 & 13.47 & 197.989 & 13.878 & 9.809 & 0.292 & 0.413 & 48.82 & 1.4534 & 4.29 & 8.98 & 2.093 \\
\hline & SRCI.3L.2 & 33.59 & 3 & 34 & 14 & 15.30 & 197.989 & 15.764 & 9.809 & 0.292 & 0.469 & 49.42 & 1.4713 & 4.29 & 7.83 & 1.825 \\
\hline & SPCI.1L.1 & 24.77 & 1 & 34 & 14 & 12.23 & 197.989 & 4.200 & 3.269 & 0.132 & 0.169 & 27.66 & 1.1167 & 2.17 & 5.58 & 2.571 \\
\hline & SPCI.3L.1 & 24.77 & 3 & 34 & 14 & 13.23 & 197.989 & 13.631 & 9.809 & 0.396 & 0.550 & 32.03 & 1.2931 & 2.17 & 6.05 & 2.788 \\
\hline \multirow{6}{*}{ II (50 Mpa) } & SRCII.1L.1 & 52.82 & 1 & 34 & 14 & 7.60 & 197.989 & 2.610 & 3.269 & 0.061 & 0.049 & 63.43 & 1.2009 & 4.07 & 4.34 & 1.066 \\
\hline & SRCII.1L.2 & 52.82 & 1 & 34 & 14 & 9.53 & 197.989 & 3.273 & 3.269 & 0.061 & 0.061 & 60.66 & 1.1484 & 4.07 & 6.49 & 1.594 \\
\hline & SRCII.3L.1 & 52.82 & 3 & 34 & 14 & 11.56 & 197.989 & 11.910 & 9.809 & 0.185 & 0.225 & 67.37 & 1.2755 & 4.07 & 7.77 & 1.909 \\
\hline & SRCII.3L.2 & 52.82 & 3 & 34 & 14 & 10.11 & 197.989 & 10.416 & 9.809 & 0.185 & 0.197 & 70.81 & 1.3406 & 4.07 & 6.01 & 1.476 \\
\hline & SPCII.1L.1 & 48.53 & 1 & 34 & 14 & 7.34 & 197.989 & 2.520 & 3.269 & 0.067 & 0.051 & 52.52 & 1.0822 & 3.38 & 4.03 & 1.192 \\
\hline & SPCII.3L.1 & 48.53 & 3 & 34 & 14 & 9.88 & 197.989 & 10.179 & 9.809 & 0.202 & 0.209 & 58.25 & 1.2003 & 3.38 & 6.72 & 1.988 \\
\hline \multirow{6}{*}{ III (62 Mpa) } & SRCIII.1L.1 & 63.79 & 1 & 34 & 14 & 5.78 & 197.989 & 1.985 & 3.269 & 0.051 & 0.031 & 72.86 & 1.1422 & 3.75 & 3.85 & 1.026 \\
\hline & SRCIII.1L.2 & 63.79 & 1 & 34 & 14 & 5.71 & 197.989 & 1.961 & 3.269 & 0.051 & 0.030 & 76.82 & 1.2043 & 3.75 & 3.89 & 1.037 \\
\hline & SRCIII.3L ${ }_{.1}$ & 63.79 & 3 & 34 & 14 & 7.16 & 197.989 & 7.377 & 9.809 & 0.153 & 0.115 & 79.58 & 1.2475 & 3.75 & 5.02 & 1.338 \\
\hline & SRCIII.3L.2 & 63.79 & 3 & 34 & 14 & 8.76 & 197.989 & 9.025 & 9.809 & 0.153 & 0.141 & 79.60 & 1.2478 & 3.75 & 5.26 & 1.402 \\
\hline & SPCIII.1L.1 & 59.53 & 1 & 34 & 14 & 3.97 & 197.989 & 1.363 & 3.269 & 0.054 & 0.022 & 61.30 & 1.0297 & 3.56 & 3.69 & 1.036 \\
\hline & SPCIII.3L.1 & 59.53 & 3 & 34 & 14 & 6.69 & 197.989 & 6.893 & 9.809 & 0.164 & 0.115 & 70.35 & 1.1818 & 3.56 & 4.94 & 1.387 \\
\hline
\end{tabular}

Table 8. Data and results of CFRP-confined square concrete specimens 
Table 9. Performance of proposed model: compressive strength

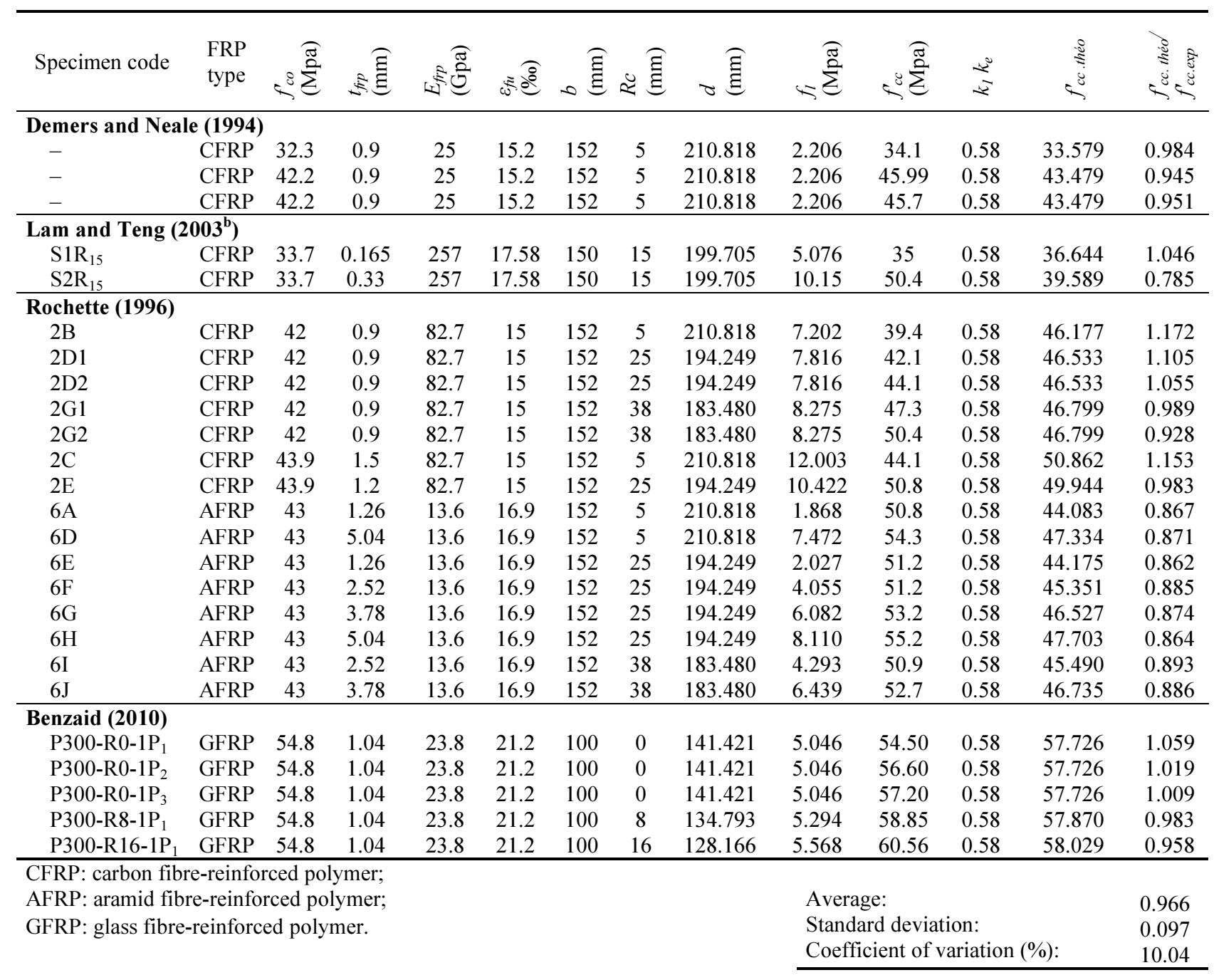

\section{Proposed equation}

Based on the linear equation previously proposed by Richart et al. (1929) for uniformly confined concrete, the proposed model employs similar approach with several modifications accounting for the effect of the shape, effective FRP strain and effective confinement. The compressive strength of a square FRP-confined concrete column is proposed to be a simple modification of Eqn (7) by the introduction of a confinement effectiveness coefficient denoted $k_{e}$. Thus:

$$
\frac{f_{c c}^{\prime}}{f_{c o}^{\prime}}=1+k_{1} k_{e} \frac{f_{l}}{f_{c o}^{\prime}},
$$

where $k_{e} f_{l} / f^{\prime}{ }_{c o}$ is the effective confinement ratio. The coefficient $k_{l}$ was taken as 1.60 , which was suggested for uniformly confined concrete. Considering the known values of the product of the parameters $k_{l}$ and $k_{e}$ as found from expression (22) for the tested columns of this work, the values of $k_{e}$ were deduced, and were on average equal to 0.36 . Finally, the equation proposed for the confined concrete strength is:

$$
f_{c c}^{\prime}=f^{\prime}{ }_{c o}+0.58 f_{l} .
$$

\subsubsection{Axial strain at peak stress}

Similarly to the compressive strength, the axial strain at peak stress is proposed to be given by the following equation, in which a different confinement effectiveness coefficient, $k_{e 2}$, is introduced:

$$
\frac{\varepsilon_{c c}}{\varepsilon_{c o}}=2+k_{2} k_{e 2}\left(\frac{f_{l}}{f_{c o}^{\prime}}\right) .
$$

In Eqn (24), $f_{l}$ is the confining pressure in an equivalent circular column given by Eqn (15) for square section, while $k_{2}=5.55$ and $k_{e 2}=0,72$. The equation proposed for the axial strain is:

$$
\varepsilon_{c c}=\varepsilon_{c o}\left[2+4\left(\frac{f_{l}}{f_{c o}^{\prime}}\right)\right] .
$$

\subsubsection{Comparison between proposed model and existing test data}

Table 9 and 10 show comparisons between the predictions of the proposed model and the experimental results collected from other studies (Demer, Neale 1994; 
Table 10. Performance of proposed model: axial strain

\begin{tabular}{|c|c|c|c|c|c|c|}
\hline Specimen code & FRP type & $\varepsilon_{c o}$ & $\varepsilon_{c c, \exp }$ & $k_{\underline{2}} k_{e 2}$ & $\varepsilon_{c c, \text { theo }}$ & $\varepsilon_{c c, \text { theo }} / \varepsilon_{c c, \exp }$ \\
\hline \multicolumn{7}{|c|}{ Demers and Neale (1994) } \\
\hline 1 & CFRP & 0.002 & 0.004 & 4 & 0.0045 & 1.136 \\
\hline 2 & CFRP & 0.002 & 0.0035 & 4 & 0.0044 & 1.262 \\
\hline 3 & CFRP & 0.002 & 0.0035 & 4 & 0.0044 & 1.262 \\
\hline \multicolumn{7}{|c|}{ Lam and Teng (2003b) } \\
\hline $\mathrm{S}_{1} \mathrm{R}_{15}$ & CFRP & 0.001989 & 0.004495 & 4 & 0.0051 & 1.151 \\
\hline $\mathrm{S}_{2} \mathrm{R}_{15}$ & CFRP & 0.002 & 0.0087 & 4 & 0.0064 & 0.736 \\
\hline \multicolumn{7}{|l|}{ Rochette (1996) } \\
\hline $2 \mathrm{~B}$ & CFRP & 0.003 & 0.0069 & 4 & 0.0080 & 1.167 \\
\hline 2D1 & CFRP & 0.003 & 0.0094 & 4 & 0.0082 & 0.875 \\
\hline 2D2 & CFRP & 0.003 & 0.0089 & 4 & 0.0082 & 0.925 \\
\hline 2G1 & CFRP & 0.003 & 0.0108 & 4 & 0.0083 & 0.774 \\
\hline $2 \mathrm{G} 2$ & CFRP & 0.003 & 0.0116 & 4 & 0.0083 & 0.721 \\
\hline $2 \mathrm{C}$ & CFRP & 0.003 & 0.0102 & 4 & 0.0092 & 0.909 \\
\hline $2 \mathrm{E}$ & CFRP & 0.003 & 0.0135 & 4 & 0.0088 & 0.655 \\
\hline $6 \mathrm{~A}$ & AFRP & 0.003 & 0.0106 & 4 & 0.0065 & 0.615 \\
\hline $6 \mathrm{D}$ & AFRP & 0.003 & 0.0124 & 4 & 0.0080 & 0.652 \\
\hline $6 \mathrm{E}$ & AFRP & 0.003 & 0.0079 & 4 & 0.0065 & 0.831 \\
\hline $6 \mathrm{~F}$ & AFRP & 0.003 & 0.0097 & 4 & 0.0071 & 0.735 \\
\hline $6 \mathrm{G}$ & AFRP & 0.003 & 0.011 & 4 & 0.0076 & 0.699 \\
\hline $6 \mathrm{H}$ & AFRP & 0.003 & 0.0126 & 4 & 0.0082 & 0.655 \\
\hline $6 \mathrm{I}$ & AFRP & 0.003 & 0.0096 & 4 & 0.0071 & 0.749 \\
\hline $6 \mathrm{~J}$ & AFRP & 0.003 & 0.0118 & 4 & 0.0077 & 0.660 \\
\hline \multicolumn{7}{|l|}{ Benzaid (2010) } \\
\hline P300-R0-1P & GFRP & 0.0025 & 0.0088 & 4 & 0.0059 & 0.672 \\
\hline $\mathrm{P} 300-\mathrm{R} 0-1 \mathrm{P}_{2}$ & GFRP & 0.0025 & 0.0090 & 4 & 0.0059 & 0.657 \\
\hline P300-R0-1P 3 & GFRP & 0.0025 & 0.0098 & 4 & 0.0059 & 0.604 \\
\hline P300-R8-1P 1 & GFRP & 0.0025 & 0.0091 & 4 & 0.0059 & 0.655 \\
\hline \multirow[t]{4}{*}{$\mathrm{P} 300-\mathrm{R} 16-1 \mathrm{P}_{1}$} & GFRP & 0.0025 & 0.0098 & 4 & 0.0060 & 0.613 \\
\hline & \multicolumn{4}{|c|}{ Average: } & \multicolumn{2}{|c|}{0.815} \\
\hline & \multicolumn{4}{|c|}{ Standard deviation: } & \multicolumn{2}{|c|}{0.214} \\
\hline & \multicolumn{4}{|c|}{ Coefficient of variation (\%): } & \multicolumn{2}{|c|}{26.30} \\
\hline
\end{tabular}

Rochette 1996; Lam, Teng 2003b; Benzaid 2010) for the compressive strength and the axial strain at peak stress of FRP-confined concrete in square sections. Clearly, the present model is more accurate in predicting the compressive strength but less accurate in predicting the axial strain. Accurate predictions of the axial strain are an issue that will require a great deal of further research.

\section{Conclusions}

This work investigates the behaviour of confined short column with different cross section geometry and degree of confinement. The obtained results showed that the efficiency of the confinement is very sensitive to the column cross section geometry (circular and square), the confining stress expressed in the number of the CFRP sheet layers applied and the strength of unconfined concrete.

- The CFRP confinement on low-strength concrete specimens produced higher results in terms of strength and strains than for high-strength concrete similar specimens. Therefore, the confinement effectiveness reduces with an increase in the unconfined concrete strength for both circular and square FRP-confined concrete specimens.

-Increasing the amount of CFRP sheets produce an increase in the compressive strength of the confined column but with a rate lower compared to that of the deformation capacity.
- The failure of CFRP wrapped specimens occurred in a sudden and explosive way preceded by typical creeping sounds. For cylindrical specimens, the fibre rupture starts mainly in their central zone, then propagates towards other sections. Regarding confined concrete prisms, failure initiated at or near a corner, because of the high stress concentration at these locations.

- The efficiency of the CFRP confinement is higher for circular than for square sections, as expected. The increase of ultimate strength of sharp edged sections is low, although there is a certain gain of load capacity and of ductility.

- In existing models for FRP-confined concrete, it is commonly assumed that the FRP ruptures when the hoop stress in the FRP jacket reaches its tensile strength from either flat coupon tests which is herein referred to as the FRP material tensile strength. However, experimental results show that the FRP material tensile strength was not reached at the rupture of FRP in FRP-confined concrete and specimen's failure occurs before the FRP reached their ultimate strain capacities. The failure occurs prematurely and the circumferential failure strain was lower than the ultimate strain obtained from standard tensile testing of the FRP composite. This phenomenon considerably affects the accuracy of the existing models for FRP-confined concrete. Thus, 
on the basis of the effective lateral confining pressure of composite jacket and the effective circumferential FRP failure strain a new equations were proposed to predict the strength of FRP-confined concrete and corresponding strain for each of the cross section geometry used, circular and square.

Further work is required to verify the applicability of the proposed models over a wider range of geometric and material parameters, to improve their accuracy (particularly that of the axial strain at peak stress) and to place them on a clear mechanical basis. Both additional tests and theoretical investigation are needed.

\section{Acknowledgements}

Authors thankfully acknowledge the support of Sika France S.A. (Saint-Grégoire, Rennes) for providing the fibre-reinforced polymer materials.

\section{References}

Almusallam, T. H. 2007. Behavior of normal and high-strength concrete cylinders confined with E-glass/epoxy composite laminates, Composites Part B 38: 629-639. http://dx.doi.org/10.1016/j.compositesb.2006.06.021

Becque, J.; Patnaik, A.; Rizkalla, S. H. 2003. Analytical models for concrete confined with FRP tubes, ASCE Journal of Composites for Construction 7(1): 31-8. http://dx.doi.org/10.1061/(ASCE)10900268(2003)7:1(31)

Benzaid, R. 2010. Contribution à l'étude des matériaux composites dans le renforcement et la réparation des eléments structuraux linéaires en béton: Thèse de Doctorat, INSA de Rennes, France, 280 p. (in French).

Benzaid, R.; Chikh, N. E.; Mesbah, H. 2008. Behaviour of square concrete columns confined with GFRP composite wrap, Journal of Civil Engineering and Management 14(2): 115-120.

http://dx.doi.org/10.3846/1392-3730.2008.14.6

Benzaid, R.; Chikh, N. E.; Mesbah, H. 2009. Study of the compressive behavior of short concrete columns confined by fiber reinforced composite, Arabian Journal for Science and Engineering 34(1B): 15-26.

Benzaid, R.; Mesbah, H.; Chikh, N. E. 2010. FRP-confined concrete cylinders: axial compression experiments and strength model, Journal of Reinforced Plastics and Composites 29(16): 2469-2488.

http://dx.doi.org/10.1177/0731684409355199

Berthet, J. F.; Ferrier, E.; Hamelin, P. 2006. Compressive behavior of concrete externally confined by composite jackets - part B: modeling, Construction and Building Materials 20: 338-347.

http://dx.doi.org/10.1016/j.conbuildmat.2005.01.029

Campione, G.; Miraglia, N.; Papia, M. 2004. Strength and strain enhancements of concrete columns confined with FRP sheets, Journal of Structural Engineering and Mechanics 18(6): 769-790. http://dx.doi.org/10.12989/sem.2004.18.6.769

Chaallal, O.; Hassen, M.; Shahawy, M. 2003. Confinement model for axially loaded short rectangular columns strengthened with FRP polymer wrapping, ACI Structural Journal 100(2): 215-221.

Cusson, D.; Paultre, P. 1995. Stress-strain model for confined high-strength concrete, ASCE Journal of Structural Engineering 121(3): 468-477.

http://dx.doi.org/10.1061/(ASCE)0733-

9445(1995)121:3(468)
De Lorenzis, L.; Tepfers, R. 2003. A comparative study of models on confinement of concrete cylinders with fiberreinforced polymer composites, ASCE Journal of Composites for Construction 7(3): 219-237.

http://dx.doi.org/10.1061/(ASCE)1090-

0268(2003)7:3(219)

De Lorenzis, L.; Tepfers, R. 2001. A comparative study of models on confinement of concrete cylinders with FRP composites. Work No. 46, Publication 01:04. Division of Building Technology, Chalmers University of Technology, Sweden. 81 p.

Demer, M.; Neale, K. W. 1994. Strengthening of concrete columns with unidirectional composite sheets, in Mufti, A. A.; Bakht, B.; Jaeger, L. G. (Eds). Development in Short and Medium Span Bridge Engineering'94, Proceedings of the fourth International Conference on Short and Medium Span Bridges, Canadian Society For Civil Engineering, Montreal, Canada, 895-905.

Fardis, M. N.; Khalili, H. H. 1982. FRP-encased concrete as a structural material, Magazine of Concrete Research 34(121): 191-202. http://dx.doi.org/10.1680/macr.1982.34.121.191

Ilki, A. 2006. FRP strengthening of RC columns (Shear, Confinement and Lap Splices), in Retrofitting of Concrete Structures by Externally Bonded FRPs, with Emphasis on Seismic Applications, Fib Bulletin 35, Lausanne, Swiss, $123-142$.

Ilki, A.; Kumbasar, N.; Koç, V. 2003. Low and medium strength concrete members confined by fiber reinforced polymer jackets, ARI The Bulletin of the Istanbul Technical University 53(1): 118-123.

Jiang, T.; Teng, J. G. 2007. Analysis-oriented stress-strain models for FRP-confined concrete, Engineering Structures 29: 2968-2986. http://dx.doi.org/10.1016/j.engstruct.2007.01.010

Karabinis, A. I.; Rousakis, T. C. 2001. A model for the mechanical behaviour of the FRP confined columns, in Proceedings of the International Conference on FRP Composites in Civil Engineering, Hong Kong, China, 317-326.

Karbhari, V. M.; Gao, Y. 1997. Composite jacketed concrete under uniaxial compression - verification of simple design equations, ASCE Journal of Materials in Civil Engineering 9(4): 185-193.

http://dx.doi.org/10.1061/(ASCE)0899-

1561(1997)9:4(185)

Lam, L.; Teng, J. G. 2002. Strength models for fiber-reinforced plastic confined concrete, ASCE Journal of Structural Engineering 128(5): 612-623.

http://dx.doi.org/10.1061/(ASCE)07339445(2002)128:5(612)

Lam, L.; Teng, J. G. 2003b. Design-oriented stress-strain model for FRP-confined concrete in rectangular columns, Journal of Reinforced Plastics and Composites 22(13): 11491186. http://dx.doi.org/10.1177/0731684403035429

Lam, L.; Teng, J. G. 2003a. Design-oriented stress-strain model for FRP confined concrete, Construction and Building Materials 17: 471-489. http://dx.doi.org/10.1016/S0950-0618(03)00045-X

Lam, L.; Teng, J. G.; Cheung, C. H.; Xiao, Y. 2006. FRPconfined concrete under axial cyclic compression, Cement and Concrete Composites 28: 979-958.

http://dx.doi.org/10.1016/j.cemconcomp.2006.07.007

Malvar, L. J.; Morrill, K. B.; Crawford, J. E. 2004. Numerical modeling of concrete confined by fiber-reinforced composites, ASCE Journal of Composites for Construction 8(4): 315-322.

http://dx.doi.org/10.1061/(ASCE)1090-0268(2004)8:4(315) 
Mander, J. B.; Priestley, M. J. N.; Park, R. 1988. Theoretical stress-strain model for confined concrete, ASCE Journal of Structural Engineering 114(8): 1804-1826. http://dx.doi.org/10.1061/(ASCE)07339445(1988)114:8(1804)

Matthys, S.; Toutanji, H.; Audenaert, K.; Taerwe, L. 2005. Axial load behavior of large-scale columns confined with fiber-reinforced polymer composites, ACI Structural Journal 102(2): 258-267.

Mirmiran, A.; Shahawy, M. 1997. Behavior of concrete columns confined by fiber composites, ASCE Journal of Structural Engineering 123(5): 583-590. http://dx.doi.org/10.1061/(ASCE)07339445(1997)123:5(583)

Mirmiran, A.; Shahawy, M.; Samaan, M.; El Echary, H. 1998. Effect of column parameters on FRP-confined concrete, ASCE Journal of Composites for Construction 2(4): 175185.

Miyauchi, K.; Inoue, S.; Kuroda, T.; Kobayashi, A. 1999. Strengthening effects of concrete columns with carbon fiber sheet, Transactions of the Japan Concrete Institute 21: $143-150$.

Moran, D. A.; Pantelides, C. P. 2002. Variable strain ductility ratio for fiber reinforced polymer-confined concrete, ASCE Journal of Composites for Construction 6(4): 224-232. http://dx.doi.org/10.1061/(ASCE)10900268(2002)6:4(224)

NF EN ISO 527-1: 1993. Determination of tensile properties of plastics materials. Part 1: general principles. ISO International Standards. $9 \mathrm{p}$.

NF EN ISO 527-2: 1993. Determination of tensile properties of plastics materials. Part 2: test conditions for moulding and extrusion plastics. ISO International Standards. $5 \mathrm{p}$.

NF EN ISO 527-5: 1997. Determination of tensile properties of plastics materials. Part 5: test conditions for unidirectional fibre-reinforced plastic composites. ISO International Standards. 9 p.

Park, R.; Paulay, T. 1975. Reinforced concrete structures. New York: John Wiley and Sons. $800 \mathrm{p}$. http://dx.doi.org/10.1002/9780470172834

Piekarczyk, J.; Piekarczyk, W.; Blazewicz, S. 2011. Compression strength of concrete cylinders reinforced with carbon fiber laminate, Construction and Building Materials 25: 2365-2369. http://dx.doi.org/10.1016/j.conbuildmat.2010.11.035

Richart, F. E.; Brandtzaeg, A.; Brown, R. L. 1929. The failure of plain and spirally reinforced concrete in compression. Bulletin No. 190, Engineering Experiment Station, University of Illinois, Urbana, USA.

Rochette, P. 1996. Confinement de colonnes courtes en béton de section carrée ou rectangulaire avec des matériaux composites, Maîtrise Es-Sciences Appliquées, Université de Sherbrooke, Canada. 115 p. (in French).

Rochette, P.; Labossière, P. 2000. Axial testing of rectangular column models confined with composites, ASCE Journal of Composites for Construction 4(3): 129-136.

Rousakis, T. C.; Karabinis, A. I. 2008. Substandard reinforced concrete members subjected to compression: FRP confining effects, RILEM Materials and Structures 41(9): 15951611. http://dx.doi.org/10.1617/s11527-008-9351-4
Saadatmanesh, H.; Ehsani, M. R.; Li, M. W. 1994. Strength and ductility of concrete columns externally reinforced with composites straps, ACI Structural journal 91(4): 434-447.

Saafi, M.; Toutanji, H. A.; Li, Z. 1999. Behavior of concrete columns confined with fiber reinforced polymer tubes, ACI Materials Journal 96(4): 500-509.

Samaan, M.; Mirmiran, A.; Shahawy, M. 1998. Model of confined concrete by fiber composites, ASCE Journal of Structural Engineering 124(9): 1025-1031. http://dx.doi.org/10.1061/(ASCE)07339445(1998)124:9(1025)

Shahawy, M.; Mirmiran, A.; Beitelman, T. 2000. Tests and modeling of carbon-wrapped concrete columns, Composites Part B 31(6): 471-480. http://dx.doi.org/10.1016/S1359-8368(00)00021-4

Shehata, I. A. E. M.; Carneiro, L. A. V.; Shehata, L. C. D. 2002. Strength of short concrete columns confined with CFRP sheets, RILEM Materials and Structures 35: 50-58. http://dx.doi.org/10.1617/13686

Siddhawartha, M.; Hoskin, A.; Fam, A. 2005. Influence of concrete strength on confinement effectiveness of fiberreinforced polymer circular jackets, ACI Structural Journal 102(3) 383-392.

Spoelstra, M. R.; Monti, G. 1999. FRP-confined concrete model, ASCE Journal of Composites for Construction 3(3): $143-150$.

Teng, J. G.; Chen, J. F.; Smith, S. T.; Lam, L. 2002. FRP strengthened RC structures. Chichester: John Wiley and Sons Ltd. $245 \mathrm{p}$.

Teng, J. G.; Huang, Y. L.; Lam, L.; Ye, L. P. 2007. Theoretical model for fiber reinforced polymer-confined concrete, ASCE Journal of Composites for Construction 11(2): 201-210.

Thériault, M.; Neale, K. W. 2000. Design equations for axiallyloaded reinforced concrete columns strengthened with FRP wraps, Canadian Journal of Civil Engineering 27(5): 1011-1020. http://dx.doi.org/10.1139/100-019

Toutanji, H. 1999. Stress-strain characteristics of concrete columns externally confined with advanced fiber composite sheets, ACI Materials Journal 96(3): 397-404.

Vintzileou, E.; Panagiotidou, E. 2008. An empirical model for predicting the mechanical properties of FRP-confined concrete, Construction and Building Materials 22: 841854. http://dx.doi.org/10.1016/j.conbuildmat.2006.12.009

Wu, G.; Lu, Z. T.; Wu, Z. S. 2006. Strength and ductility of concrete cylinders confined with FRP composites, Construction and Building Materials 20: 134-148. http://dx.doi.org/10.1016/j.conbuildmat.2005.01.022

Xiao, Y.; Wu, H. 2003. Compressive behavior of concrete confined by various types of FRP composite jackets, Journal of Reinforced Plastics and Composites 22(13): 11871201. http://dx.doi.org/10.1177/0731684403035430

Yang, X.; Nanni, A.; Chen, G. 2001. Effect of corner radius on the performance of externally bonded reinforcement, in Proceedings of The Fifth International Symposium on Fiber Reinforced Polymer for Reinforced Concrete Structures (FRPRCS-5), Cambridge, London, 197-204.

Youssef, M. N.; Feng, M. Q.; Mosallam, A. S. 2007. Stressstrain model for concrete confined by FRP composites, Composites: Part B 38: 614-628. http://dx.doi.org/10.1016/j.compositesb.2006.07.020

Riad BENZAID. Associate Professor at the University of Jijel (Algeria). Researcher at the L.G.G. laboratory at Jijel University and at the L.M.D.C. laboratory of Materials at Mentouri University - Constantine (Algeria). His main research interests include strengthening the concrete elements with FRP materials.

Habib-Abdelhak MESBAH. Associate Professor at the University of Rennes 1, France (I.U.T of Rennes). Researcher at the L.G.C.G.M. laboratory at INSA of Rennes (France). His research interests include self-consolidating concrete, high performance concrete, fibre reinforced concrete, strengthening the concrete elements with FRP materials. 